Historic, Archive Document

Do not assume content reflects current scientific knowledge, policies, or practices. 



\section{Illustrated Price Catalog}

Nineteen Hundred Eighteen-Nineteen
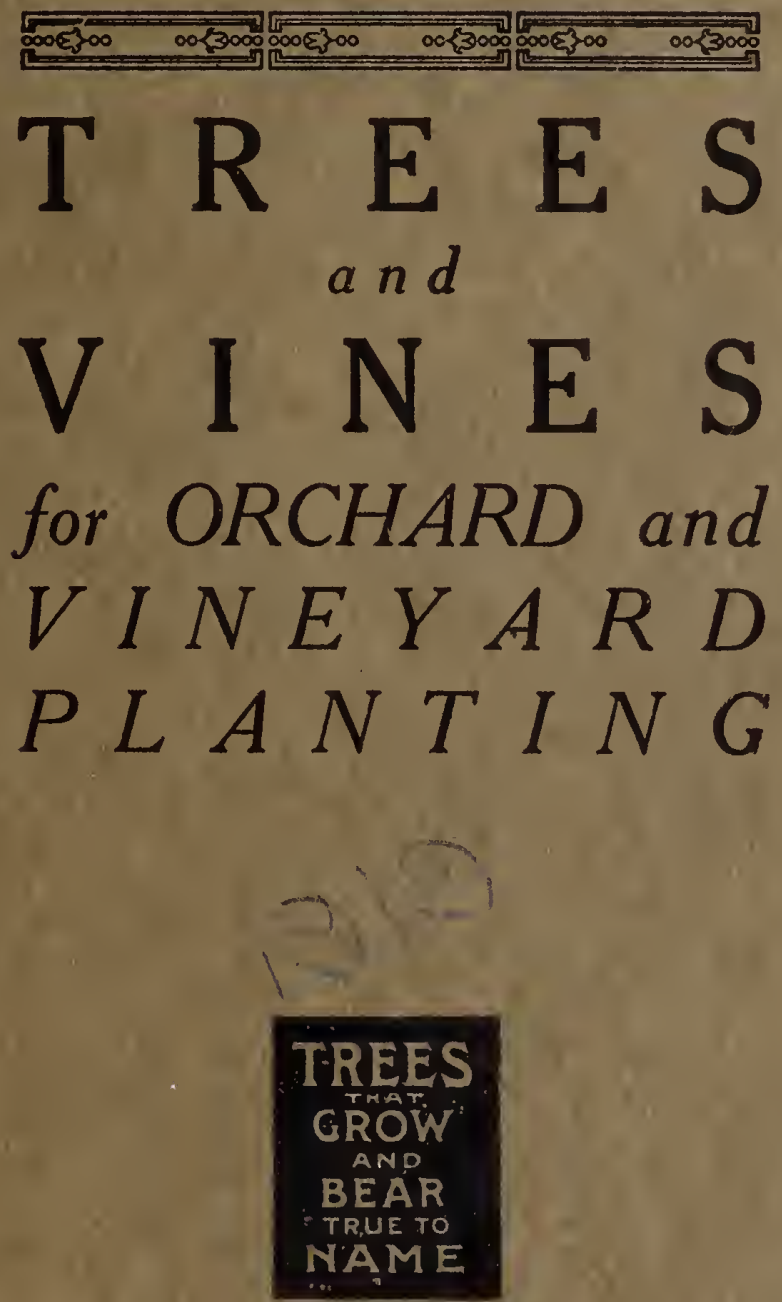

KIRKMAN NURSERIES, Inc. ESTABLISHED 1888

Corner of Tulare and O Streets

FRESNO, CALIFORNIA 


\section{PLANTING AND PRUNING}

\section{PREPARING TO PLANT}

The first step toward planting an orchard is to get the land in proper shape. This calls for deep plowing and the use of a subsoiler if possible. Then, where irrigation is to be practiced, the land should be put on proper grades to allow of convenient flow of the water. The surface should be harrowed until smooth and free from clods.

A few orchards are set out on the equilateral triangle method, but this arrangement does not permit of thinning trees by removal of alternate rows as is sometimes advisable, and one has to take a zig-zag course in driving across the orchard.

Much attention is now being given to "permanent trees" and "fillers." By permanent trees" we mean, for instance Figs, Olives or Walnuts. These long lived varieties can be planted at proper distances, say 40 feet, and "fillers" of short lived varieties which come into bearing earlier in life used to fill in the 20 foot spaces. Thus giving 27 Figs or Olives or Walnuts and 81 fillers. After ten or twelve years two-thirds of the fillers can be removed leaving one filler in the center of each square for another term of a few years. In one of our own orchards enough income was gotten from peach fillers the third summer (two and one-half years after planting) to pay for the care of the orchard for the year.

Deciduous trees should be planted in January, February or March. Citrus trees should not be planted before the middle of March and better in April or May. Olives do best after the middle of April.

On receipt of shipment of trees or vines they should be unpacked and unless planted immediately, be set out in trenches and the dirt well settled about the roots with water. If the trees are kept in trench very long they should be very frequently irrigated, as much of the failure of trees to grow is attributable to drying out before planting."

Holes should be dug large enough to receive the roots of the trees without crowding. In general eighteen inches across and the same depth are satisfactory dimensions, but many of the ordinary deciduous trees will need holes two feet deep, and walnuts are dug with such long roots that at least two and one-half feet is, the necessary depth for the hole. In some sections where "hard pan" lies closer than three or four feet from the surface it is advisable to blast out the bottom of the hole in order to give the roots an opportunity to get down to a proper depth.

\section{PLANTING}

Having dug the holes, the trees should be planted at once, and particular care exercised to avoid exposure of the roots during distribution about the field. The roots of most varieties should be shortened back, leaving clean cut, and any bruised or diseased roots cut away. The trees should be set in the hole with the union of the top and root \& little below where the level of the ground will bo and top soil filled in around the roots. The earth should be tramped firmly in around the roots, but particular care should be taken not to bruise them. The hole should not be filleu quite to the top, but a little basin left, and as soon as possible after plainting this should be filled with water either by tank-wagon and bucket, or by irrigation. The next day after watering the trees, the holes should be filled up with loose dirt.

\section{PRUNING THE YOUNG ORCHARD}

Practically all deciduous fruit trees should be headed back at planting. This may bo done before, but can better be left till after planting. Better work will be done, more attention being given to each individual tree.

Too much attention cannot be paid to this part of the art of horticulture, and the planter will do well to make a study of the question as applied to his own local conditions and the variety of trees he is raising. Prun ing science is at present in a transitional stage. There is a back-to-nature tendency in direct opposition to the accepted ideas of the recent past. Up-to-date orchardists are using the shears and saw less and less each year, directing the efforts to removal of unnecessary and objectionable branches rather than to shortening back all the growth each year. The short life of many of our California orchards is attributed by experienced growers to overzealousness in this matter of cutting back the growth each year instead of letting the trees go ahead in their natural way. There certainly must be a happy medium by which the orchardists can secure proper shape and bearing surface and yet retain the natural vitality of his trees.

\section{PROTECTING THE YOUNG TREES}

In the case of most all trees, particularly in districts where there is a tendency for the stems to become sunburned, or where rabbits and squirrels are troublesome, it is advisable to furnish protection for the trunks during the first year or two. 


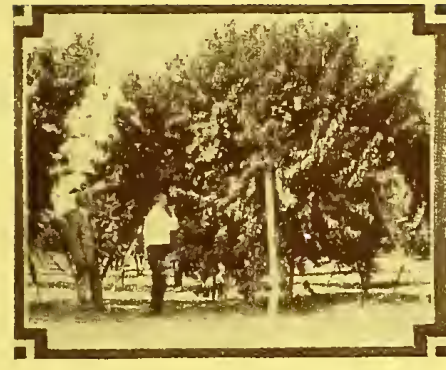

4-Year-Old Peach Orchard

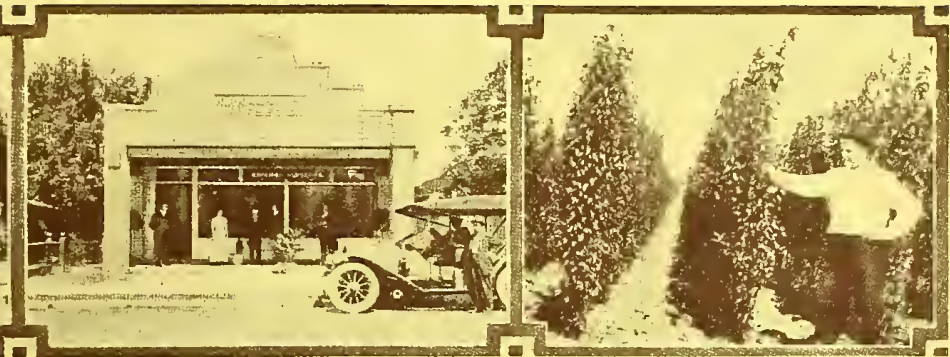

Main Office, Fresno

\title{
The KIRKMAN NURSERIES, Inc.
}

\author{
ESTABLISHED 1888
}

PAID UP CAPITAL - $\$ 100.000 .00$

WILLIAM T. KIRKMAN, Jr. President and PrCanager

We have had difficulties to contend with during the past two years. Nevertheless our work has gone on and we offer in this, our 30th year, the largesi stock of Deciduous and Citrus Fruit Trees and Grape Vines grown by any Nursery in the West. To do this we discontinued our Ornamental Department.

Along our special lines we aim to be of greatest possible service to the planting public and if any information is desired write us-we'll try to help you out. An elaborate catalog does not seem advisable this year. We are now putting in our entire effort preparing our magnificent stock for delivery.

One of our old customers is taking 50,000 trees this year. Another order is for 200,000 trees. These men know our trees are DEPENDABLE. $Y$ ou can safely place your order with us no matter what its size may be.

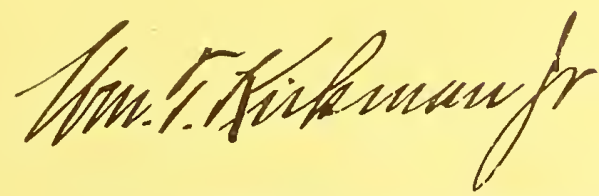

President Kirkman Nurseries. 


\section{DECIDUOUS FRUITS AND NUTS}

\section{ALMONDS}

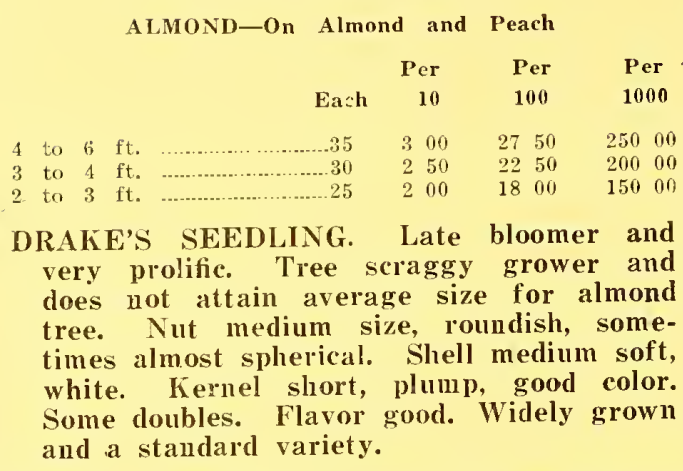

Eureka. Tree exceptionally strong grower and heavy bearer. This variety is very popular when it has been tried out. The nut is a favorite with confectioners.

I. X. L. Tree large, with upright habit of growtl. Nut very large and symmetrical. Shell soft and smooth. Kernel large and plump. Widely grown and a standard variety on the market.

Jordan. The Spanish almond of commerce. Poor grower. Blossoms among the very earliest and is regarded as a sliy bearer. The nut is long, narrow, with hard, smooth shell. The kernel is long, smooth and very plump. It has a thin skin and blanches easily. Flavor excellent.

LANGUEDOC. Introduced from France. Tree vigorous, upright grower, and long lived. Blooms late and bears abumdantly. Nuts medium size. Broad at base, tapering to apex. Shell fairly soft, white. Kemel short, broad and plump. Light colored and excellent flavor. A very heavy yielder.

lewelling's Prolific. Tree upright, vigorous grower. Blooms medium late and bears abundantly. Nut short, broad. Shell medium soft and very dark, not bleaching well. Kernel short, conical, plump.

NE PLUS ULTRA... Tree of rather drooping growth. Nut long, narrow, with thick, soft shell. Point characteristically curved. Ker nel long, sleider, of good flavor.

NONPARIEL. Tree very vigorous grower but of rather weeping habit. Nit large, long and narrow. Shell very thin, and of good color. Kernel long, narrow, plump, of light color and excellent flavor. Highest priced almond ou the market. Blooms early and is, under proper conditions, a good yielder.

PEERLESS. Tree low, compact grower. Nut roundish and symmetrical, like I. X. L. in shape. Shell medium soft, smooth, white.
Kernel short, plump, some doubles. Quality good. Grown widely in Sacramento Valley and worthy of more credit.

-Smith I. X. L. Originated near Oakley, Cal. on the place of Geo. Smith. Mr. E. W. Robbins of Oakley gives the following description:

"Tree a magnificent grower; outgrows all other varieties; sure cropper. In eighteen years the original trees have never missed a crop. Begins to bear bumper crops very young. Stands much frost after blooming; nuts large, soft shell, maturing very early.

My largest trees (two-year-grafts) have as much as twenty to thirty pounds of almonds (hulled) this season

TEXAS PROLIFIC... Tree vigorous with upright, open growth. Late bloomer and prolific bearer. Nut medium size, of Languedoc shape. Sliell medium soft, smooth, white. Kernel short, broad, plump and very sweet.

\section{APPLES}

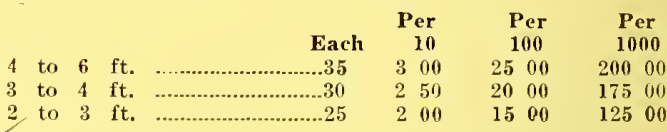

Arkansas Black. Large, round or slightly conical, regular, smooth, glossy yellow, where not covered with deep crimson, almost black. Flesh yellow, firm; finegained, juicy; flavor sub-acid, pleasant, rich. December to April.

Bellefleur. Large, yellow, with a slight blush. Tencler, juicy, sub-acid. Very valuable on medium light soils. A moderate grower and good bearer. September to January.

Ben Davis... A large, very handsome striped apple of fair quality. Tree hardy, vigorous and productive. A late keeping apple. Wellestablished favorite throughout all the West. November to January.

Bismarck. In respect to its early fiuiting habits the most remarkable apple introduced. Tree of short stocky habit; thick, healthy foliage. Fruit large, handsome; yelyow, sometimes shaded red cheeks; flesh tender, pleasant, sub-acid; good for dessert; superior for cooking. Will keep well into winter. September.

Delicious. Dark, brilliant red; large irregular. Tree hardy. When grown in high altitudes the quality is very fine. Late keeper. October to February.

Early Harvest. Medium to large, pale yellow, fine flavor. Tree moderate, erect grower and good bearer; an excellent variety for orchard and garden. July. 
Gano. Form conical; good size and smooth; deep red, shaded on sunny side to mahogany; very attractive ;flesh pale yellow, fine grained, tender; pleasant; sub-acid; is a very good shipper and keeper. Tree healthy, vigorous and hardy. An annual and prolific bearer. November to April.

Gold Ridge. Similar to its parent, Yellow Newton Pippin, but earlier. Heavy bearer and vigorous grower. Very handsome appearance. A very promising new apple. December.

Hyde's King. Large to very large; handsome yellowish green; good quality; keeps all the year round.

Gravenstein. Large, beautiful striped; tender, juicy and high flavored. Vigorous and productive. August and September.

Jonathan. Fruit medium or small, roundish; skin yellow, nearly covered with dark or lively red; fine-grained, very tender and finely flavored. Tree slender and spreading. One of the best varieties for California. October to Decenber.

liing of Tompkins County. Large, handsome striped red and yellow. Tree vigorous and productive. One of the best. October.

Lawver. Large, roundish, flat, mild sub-acid; Very heavy and hard; beautiful dark red. Handsomest of all the extra late keepers; very valuable as a late market sort. Tree a vigorous grower and very hardy; bears well. December to February.

Maiden's Blush. Medium size, flat, smooth and fair. Pale yellow with beautiful red cheek. Tender, sprightly, pleasant and acid flavor. Fair grower and good bearer. September.

Red Astrachan. Large, roundish, nearly covered with deep crimson overspread with a thick bloom. Rich, juicy, acid; making a splendid cooking apple and very fine for eating when ripe. Tree vigorous with large heavy foliage, and a good bearer. A fine apple for the hot interior valleys. July.

Red Beitigheimer. A German variety, recently introduced. Fruit large to very large, skin pale green, mostly covered with purplish crimson; flesh white, firm, sub-acid, with brisk, pleasant flavor. Tree a fine grower and abundant bearer. September.

$\checkmark$ Red June. Medium size, oblong, deep red. A good table apple. A favorite in the interior. June and July.

$\checkmark$ Rhode Island Greening. Large, greenish yellow; tender, juicy and rich. Rather acid flavor. Grows strong and spreading; abundant bearer. October to November.

$\checkmark$ Rome Beauty. Large; yellow, shaded with bright red; flesh yellowish, tender, juicy,

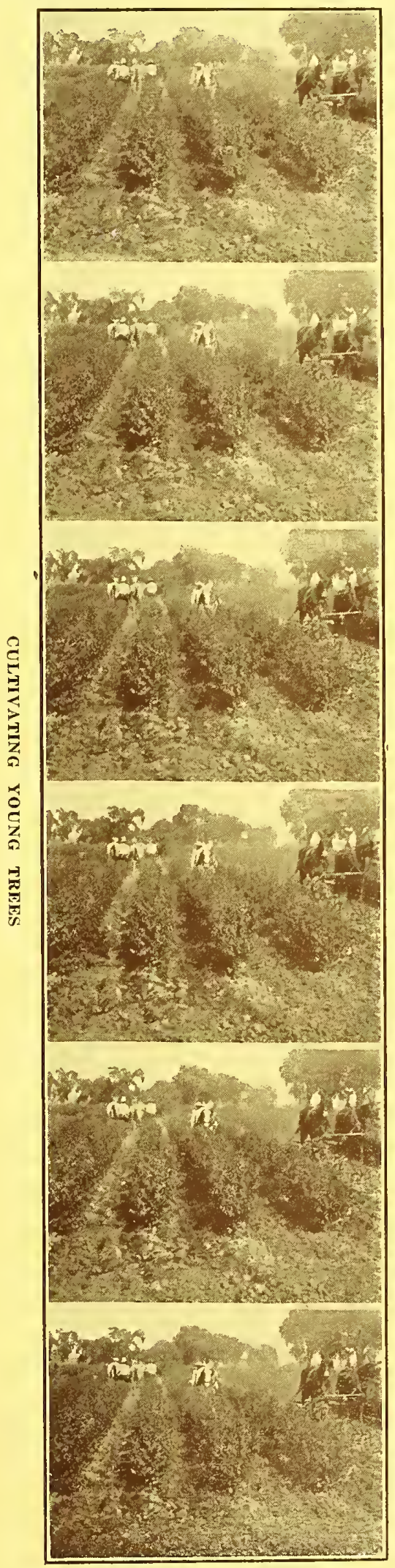


sub-acid. Moderate grower. Sure bearer and deservedly popular in California. November to February.

Skinner's Seeding. Large, yellow, striped with red. Flesh tender, juicy, best qualiity. September and October.

Smith Cider. A fine market apple. Large, handsome; yellow, striped with red; flesh juicy, crisp, sub-acid; quality medium. Tree vigorous, abundant bearer. October to Janualy.

Spitzenberg. Medium to large; deep red; flesh yellow, crisp, sub-acid, highly flavored. Tree a light grower in the nursery, but bears and grows well transplanted in rich soil. November to March.

Stayman's Winesap. Similar to Winesap, but larger and better flavored; oblate, conical, greenish yellow, striped and splashed with two shades of dark red, with numerous gray dots; flesh yellow, firm, tender, juicy, mild, sub-acid, aromatic; best quality. January to May.

White ..Astrachan. Large, roundish, skin white, streaked with red. Showy apple extensively grown in the Sacramento Valley for early shipment. July.

White Winter Pearmain. Medium size, oblong, pale greenish yellow with slight blush; brown dots. Flesh yellowish, tender, crisp, juicy; very pleasant, high flavor. A good keeper and very productive in all parts of the state. Tree a strong, healthy grower. November to January.

Winesap. Medium; dark red; sub-acid, excellent. Tree a moderate grower and abundant bearer. A favorite market variety in the West. November to February.

Winter Banana. Fruit large, perfect in form; golden yellow, and beautifully shaded and marbled with bright crimson-red; flesh lemon-yellow, fine-grained, sub-acid, rich aromatic flavor. Tree remarkably strong grower and on account of its great hardiness will thrive in any climate. Its early bearing is wonderful, generally producing a fine crop of fruit the second year. Foliage large and free from mildew. A valuable market variety. October to December.

Yellow Newton Pippin. One of the very best applies as to quality; tree is a light grower when young; fruit juicy, crisp and highly delicious flavor; fine keeper. Deservediy a favorite in California. December to May.

\section{CRAB APPLES}

CRAB APPLES-

\begin{tabular}{|c|c|c|c|c|}
\hline & & Each & 10 & 160 \\
\hline & & & $\begin{array}{r}\text { Per } \\
350\end{array}$ & $\begin{array}{c}\text { Per } \\
300\end{array}$ \\
\hline $\begin{array}{ll}10 & 0 \\
\text { to } & 4\end{array}$ & $4 \mathrm{ft}$. & 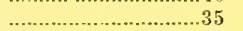 & 300 & 2500 \\
\hline to & $\mathrm{ft}$. & 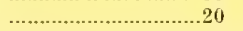 & 250 & $20 r$ \\
\hline
\end{tabular}

Yellow Siberian, Transcendent.
Transcendent. Tree remarkably vigorous, growing to a good size, and immensely productive. Bears a little the second year from planting, and produces good crops by the fourth yeal. Fruit very large. from $1 \frac{1}{2}$ to 2 inches in riameter. Excellent for pies and sauce, both green and dried. The best of its class for cider, being juicy and crisp, and is also considered a good eating apple. Skin yellow, striped with red. September.

Yellow Siberian. Fine amber or golden yellow color; fair size, fine for jelly. September.

\section{APRICOTS}

APRICOTS On Peach and Apricot.
Per
10 $\begin{gathered}\text { Per } \\ 100\end{gathered} \begin{gathered}\text { Per } \\ 1060\end{gathered}$

BLENHEIM. Large, oval; flesh full to the pit; yellow, rich and juicy; ripens evenly soon after the Royal; regular and prolific bearer; profitable for canning, drying and marketing. Middle June.

HEMSKIRK. Large, roundish, but considerably compressed or flattened on its sides; orange with rel cheelss; flech bright orange, tender; rather more juicy and sprightly than the Moorpark, with a rich and luscious plum-like flavor. Late June.

Losse. A very fine new apricot, originating in the Santa Clara Valley. Worthy of attension.

Montgamet. Fruit is large, rather flat in shape, and deep golden in color. Flesh is orange colored, rich and juicy. A good early cot; ripens early June.

Moorpark. One of the largest. Orange with a red cheek; firm, juicy, with a rich flavor; quality unexcelled; largely discarded in Ca'ifornia as a shy, irregu'ar bearer. Late June.

Newcast!e Eearly. Medium size, round, bcst early variety; two to three weeks before Royal.

Routiers Peach. Very large, handsome and of a delicious flavor; skin deep orange, mottled with dark brown; flesh of a fine saffron-yellow color; juicy, pich and highly flavored. One of the best market varieties. Middle June. 


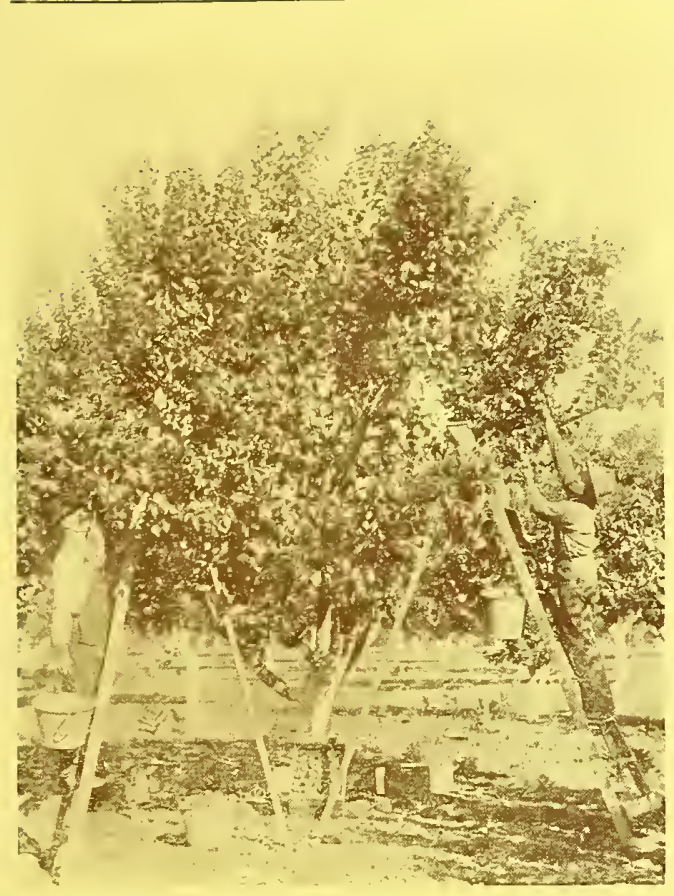

RECORD BREAKING APRICOT ORCHARD

The best bearing trees in Pajaro Valley are carefully selected for our propacation of the Royal variety. Blenheim buds from the Sunnyvale district.

ROYAL. Good sized where thinned; oval, slightly compressed; yellow with orange cheeks, faintly tinged with red; flesh pale orange, firm and juicy, with a rich vinous flavor; exceedingly productive. Early June.

TILTON. Its large size, rich apricot color, high favor, uniform ripening, sure and unusual productiveness, with frost-resisting qualities and vigorous growth, easily place it in the front rank. For drying and canning it is unsurpassed. Middle June.

\section{CHERRTES}

CHERRY-On Mazzard and Mahaleb.

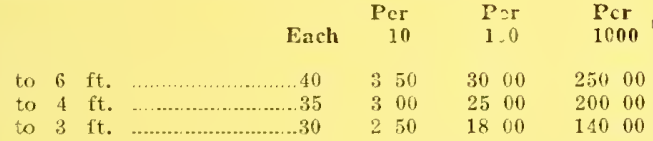

Bing. Size very large; blackish purple. Flesh very solid; flavor of the highest quality. Tree thrifty, upright grower, very hardy and productive. A fine late shipping and market variety. Middle June.

Black Oregon. (Black Republican, Lewelling.) Lal'ge, black, solid. Tlee vigorous and productive. A fine late shipper.

Black Tartarian... Very large; bright purplish black; sweet, tender, juicy, very rich; excellent flavor. Tree a vigorous g'ower and productive. Late May.
Chapman. This grand new cherry originated in Napa Valley, California, where it ripens about April 10. It is the earliest of all shipping. varieties, bears early and immense crops of fine fruit, which grows somewhat more in clusters than Black Tariarian. Size very large, form roundish, stem long and slender, surface smooth, color purplish black; flesh half tender; stone small, flavor of the highest quality.

Burhank. A large crimson cherry; very early and of the best quality. The earliest cherry in our list.

Early Richmond. Medium size; dark red; melting, juicy; sprightly acid flavor. A valuable and popular acid cherry, unsurpassed for cooking purposes. Hardy and productive. Middle May.

English Vorello. Medium to large; blackish red; rich, acid, juicy and good; very productive. July.

May Duke. Large, rich, dark red. Flesh tender, juicy, sub-acid. A fine carly cherry.

Royal Anne (Napoleon Bigarreau). A magnificent cherry of the largest size; pale yellow with bright red cheeks; flesh very firm, juicy and sweet. One of the best for market and canning. Most popular variety in California. June.

\section{FIGS}

\begin{tabular}{|c|c|c|c|c|}
\hline & Each & $\begin{array}{r}\text { Per } \\
10\end{array}$ & $\begin{array}{l}\text { Per } \\
100\end{array}$ & $\begin{array}{c}\text { Per } \\
1000\end{array}$ \\
\hline to $6 \mathrm{ft}$. & .45 & 400 & $\begin{array}{lll}35 & 00\end{array}$ & 300 on \\
\hline to $4 \mathrm{ft}$. & $\ldots 40$ & 350 & $30 \quad 00$ & 250 os \\
\hline to $3 \mathrm{ft}$. & $\ldots 35$ & 300 & 2500 & $200 \quad 00$ \\
\hline
\end{tabular}

BLACK MISSION. Large, turbinate, neck long, stalk short; skin rough, deep violet color. Regular bearer and good quality for shipeing or drying. Tree strong growing. Late June and August.

CALIMYRNA. The genuine commercial Smyrna fig as grown in Asia Minor. Large size; turbinate; skin lemon-yellow; pulp reddish amber, excellent quality fresh or dried; must be fertilized by the Blastophaga wasp. August to October.

WHITE ADRIATIC. Size, medium and roundish; skin thin, green, shaded with yellow; pulp bright red. A very popular variety, being a heavy and regular producer. Second week in August.

White Endich (Kôdota). Medium sized; on 3 of the best for canning and pickling. First week of August.

\section{CAPRIFIGS̃}

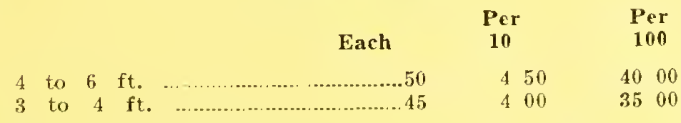

Small supply this season. An a'sortment can be furnished only in limited quantities. 
Orders can be accepted for considerable quantities for next season's planting.

Information regarding varieties now on hand furnished on application.

\section{NECTARINES}

\begin{tabular}{|c|c|c|}
\hline & Each & $\begin{array}{c}\text { Per } \\
10\end{array}$ \\
\hline 4 to $6 \mathrm{ft}$. & $\ldots \ldots \ldots+40$ & 350 \\
\hline to $4 \mathrm{ft}$. & ............. 35 & 300 \\
\hline 2 to $3 \mathrm{ft}$. & …......30 & 250 \\
\hline
\end{tabular}

Per
100
3000
2500
2000

Boston. Large, bright yellow with red cheek; flesh yellow, sweet and pleasant flavor; freestone. The leading yellow-fleshed nectaline. Late July.

Stanwick. Very large; skin greenish white, shaded with reddish violet in the sun: flesh white, tender, juicy, rich, sugary and delicious; unexcelled for drying and shipping green. profit, than does the peach. We have quite a lot of encouraging data from peach growers covering production, returns, etc., and will be glad to quote them upon request.

CLINGSTONES

\begin{tabular}{|c|c|c|c|c|c|}
\hline & & Each & $\begin{array}{r}\text { Per } \\
10\end{array}$ & $\begin{array}{l}\text { Per } \\
100\end{array}$ & $\begin{array}{l}\text { Per } \\
1000\end{array}$ \\
\hline to & $6 \mathrm{ft}$. & $\ldots 40$ & 350 & $\begin{array}{ll}30 & 00\end{array}$ & 2750 \\
\hline to & $\mathrm{ft}$. & $\ldots .35$ & 300 & 2500 & 22500 \\
\hline 2. to & $3 \mathrm{ft}$. & $\ldots .25$ & 200 & 1800 & 15000 \\
\hline
\end{tabular}

George's Late. Large, yellow splashed with red; flesh firm, juicy, white, colored at pit; tree strong grower and heavy bearer; fruit is good shipper and though of rather inferior quality sells well because of its fine appearance. Middle of September.

Hobb's Cling. A fine flavored, white cling of beautiful appearance, ripening with the Tuscan. Should be a valuable market peach.

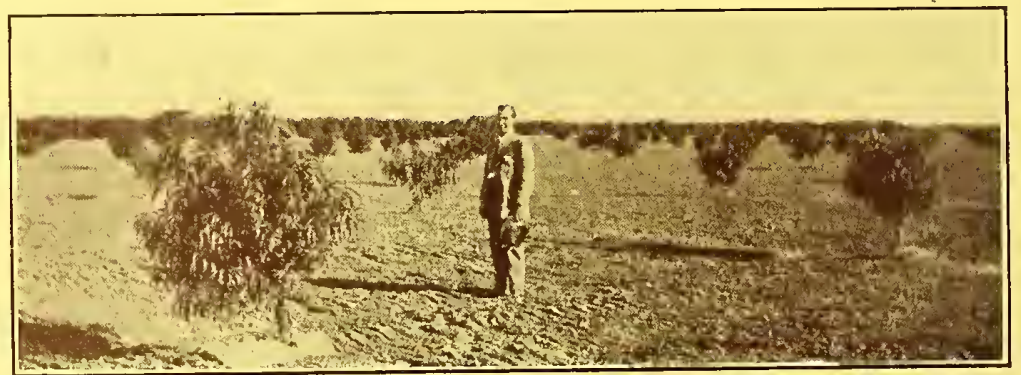

FIRST SEASON'S GROWTH PEACH ORCHARD IN SALT RIVER VALLEY. ARIZONA

\section{PEACHES}

It is not our plan to ask those who receive this descriptive price list to read any lengthy suggestions of ours as to the relative interest that should be accolded certain varieties but in the instance of the $\mathrm{PEACH}$ we feel that we would be doing less than we should if we did not go on recond as advising California orchardists, particularly of the two big interior valleys to PLANT PEACHES. This State is looked to for the supply to satisfy the steadily increasing demand for canned and dried peaches. No canning nol drying of peaches is done to any extent outside of our Statc. We have here the climatic conditions that put us beyond reach of all possible competition in the drying and canning of this fruit, and puts us in the lead in quality of freen fruit for shipment to Eastern market.

The method for peeling the dried peach now in use by the California Peach Growers Association will beyond any doubt increase the consumption of the dried product.

Thousands of households where a prejudice against the fuzzy dried peach has existed, will open to the new superior product.

We know of no other fruits that give more reliable promise of certain and satisfactory
Indian Blood Cling. Large, deep claret color, with red veins; downy; flesh red, very juicy and refreshing. Last of August.

Levy's Late, or Henrietta Cling. A magnificent cling of large size; skin a deep yellow, a shade of rich brownish red in the sun; flesh deep yellow, firm, juicy, sweet, half-melting, slightly vinous. Highly esteemed for canning and market. Middle of September.

LIBBEE CLING. This new variety, like the Peaks Cling, originated near Selma, Cal.. and is beyond much question a seedling of the Lovell variety. It bears a close resemblance to the latter, and the tree is a fine, vigorous grower, and a heavy and regular bearer of high-grade fruit of uniform size. This peach has been thoroughly tried out by canners and is pronounced to be in quality second to none. It fills an important place in the ripening period of the quartette of highest type canning peaches, viz., Tuscan, Peaks, Libbee and Phillips.

Mr. G. W. Libbee, Selma, Cal., the originator of this variety, says of it:

"I believe it one of the best canning peaches known. It ripens about the 10th of August and remains in good condition for the balance of the month. I have never found a double one. It is very late to 
blossom, making it free from frost and is of uniform size and small pit. I would surely plant the Libbee Cling first and list if I was planting more orchard.

The original tree is fifteen years old and I have never seen a curled leaf on it and it has never missed a crop."

$\checkmark$ IcDevitt's Cling. Very large, rich, golden yellow, becoming quite red when ripe; flesh yellow, firm and of superior flavor; excellent shipper and canner. Last of August.

$\checkmark$ McKevitt's Cling. White; flesh firm, rich, sugary and highly flavored; white to the pit; excellent for shipping and canning. Tree a remarkably strong grower and not subject to curl. Early September. pecially valuable for cannery purposes because of their ripening periods, between the Tuscan and Phillips.

Originated on place of J. H. Peak, two miles east of Selma, Cal. Noticeable about this peach is the remarkable evenness in size and smallness of pit. As a canning fruit it is unexcelled, and the fine appearance and firm texture should make it a good shipping and market variety.

PHILLIPS' CLING. Fine; large; yellow; flesh firm, clean yellow to pit, which is small, Best of all clings for canning. Early September.

VRed Bird Cling. Very early peach of fine appearance. A good market variety.

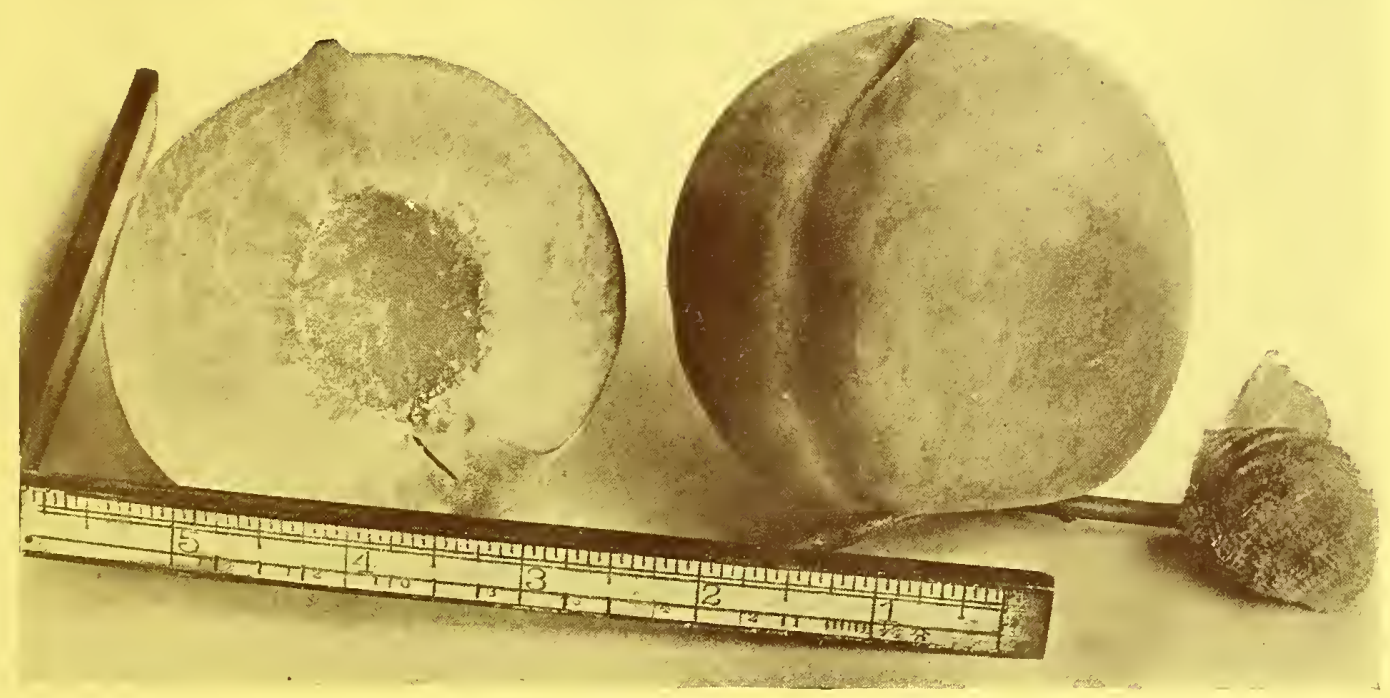

PEAK'S CLING, INTRODUCED BY US IN 1913, SEE DESCRIPTION

PEAK'S CLING. (as cescribed by F. IV. Hetherington, Supt. Libby, McNeill \& Libby Co., at Selma, Cal., in 1914): "Very much like Phillips' Cling in shape and color; a small pit like the Phillips' and is of a fine, even texture; dces not develop discoloration as easily as some clings and is a good lieeper. I have handled Mr. Peak's crop from his six acres the past three seasons and find no variation as to size or quality, the fruit sizing well and the trees bearing heavily, being hardy grower's and of heavy foliage. The fruit ripens immediately following the Tuscan."

After canning this peach for three seasons Mr. W. G. Nash, present manager of Libbey, McNeil \& Libbey cannery at Selma, states as follows:

"The Peaks' Cling is one of the best clings grown for canning purposes, resembling the Phillips in texture and color." He further states that both the Peaks' and the Libbee are good producers and es-
Runyon's Orange Cling. Fruit very large, vellow, crimson blush. Tree vigorous grower and heavy bearer. Early August.

Sims Cling. Large to very large; golden yellow, with faint blush; flesh deep yellow, of fine texture, firm and rich; pit small. Ripens middle of August.

TUSCAN CLING. A large, yellow cling, the earliest fine cling; flesh juicy and of fine flavor. A good shipping and canning peach and very desirable on account of its earliness. Ripens middle July.

White Heath Cling. A most delicious cling. Very large; skin downy, creamy white, with faint blush of red; flesh white; usually slightly red at pit; very tender, juicy and sweet; valuable for canning; season early September. 


\section{PEACHES}

\section{FREESTONES}

\begin{tabular}{|c|c|c|c|c|}
\hline & Each & Per & $\begin{array}{l}\text { Per } \\
700\end{array}$ & $\begin{array}{l}\text { Per } \\
1000\end{array}$ \\
\hline to & 35 & 300 & 2750 & 25000 \\
\hline 3 to $4 \mathrm{ft}$. & $\ldots 30$ & 250 & 2250 & 20000 \\
\hline 2 to $3 \mathrm{ft}$. & $\ldots 25$ & 200 & 1800 & 15000 \\
\hline
\end{tabular}

Admiral Dewey. Skin deep yellow, with crimson blush, flesh yellow to the pit, of fine quality. Ripens with Triumph, but of better appearance; good grower.

Alexander. Medium size; skin greenish white, nearly covered with rich red; flesh melting, juicy, sweet; tree vigorous and productive. Ripens two weeks earlier than Hale's Early. Middle June.

ELBERTA. Very large; bright yellow, with a beautifully mottled red cheek; flesh yellow, juicy, sweet; tree a uniform and regular bearer and strong grower. Fruit very showy and a perfect freestone. One of the best varieties for all purposes. Ripens last of July.

Briggs' ReI May. Fruit medium to large; skin greenish white, with rich red cheeks; flesh greenish white, melting and juicy. A standard early variety and one of the most extensively planted in California. Middle of June.

Early Crawford. Large, vellow peach, of good quality. Tree vigorous and very productive. Not so extensively planted as formerly. Middle July.

FOSTER. Large, deep orange-red, becoming very dark red on the sumny side; flesh yellow, very rich and juicy, with sub-acid flavor, ripening earlier than the Early Crawford and superior in all points; flesh is firmer, without so much red at the pit, which is smaller. Good for shipping, drying or canning. Middle July.

J. H. Hale. Freestone; larger than Elberta; globular; yellow color, almost entirely covered with bright red; thick skin and has practically no fuzz. Ripens last of July.

Hale's Early. Medium size; greenish white, with red cheek; good quality. Tree healthy, good grower and productive. One of the best early peaches. Early July.

Herold's October. Large light yellow freestone. Valuable for its extreme lateness.

Krummel's October. A magnificent yellow freestone, with profitable qualities, ripening later than the Salway, but larger and a splendid keeper; flesh firm and of a fine texture; tree a vigorous grower; fruit keeps on the tree for days after ripening. October.

Late Crawford. Fruit of large size; skin yellow, or greenish yellow, with dull red cheek; flesh yellow; tree vigorous, moderately productive. Early August.

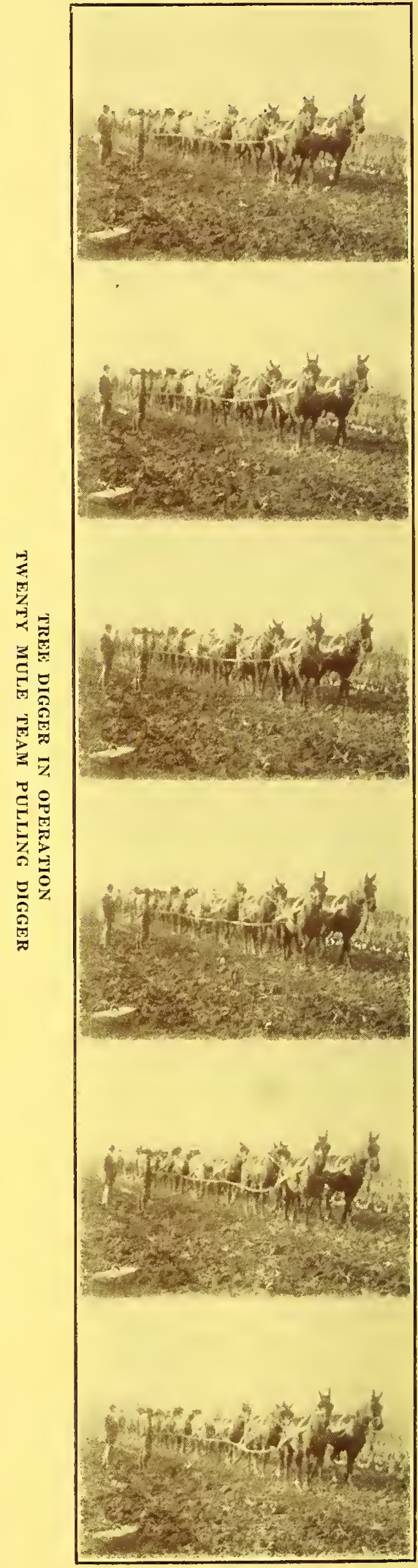


$\checkmark$ LOVELL. California seedling; large, almost perfectly round; flesh yellow to the pit, firm and of excellent quality; a superb canning, shipping and drying peach; tree a good grower and bearer. Worthy of extensive cultivation. Ripens a few days after Muir. Early August.

Mayflower. Said to be the earliest peach known; absolutely red all over; as large as Alexander. Tree a strong grower, blooms late, a heavy bearer and requires thinning. Middle June.

$\checkmark$ Morris White. Large, oval; greenish white tinged with cream when ripe; flesh white to pit, of good quality. First of August.

NIUIR. Large; perfect freestone; flesh yellow to pit, which is small; good shipper and canner, but particularly adapted to drying because of sweetness and density of flesh. Very extensively planted. Last of July.

Old Mixon Free. Large, roundish or slightly oval; greenish or yellowish white, marbled with red; flesh white, tender and excellent, juicy and rich; high flavor. Late July.

$\checkmark$ Picquet's Late. Large to very large; round, sometimes a little flattened; yellow with red cheek; flesh yellow, melting, sweet, rich and fragrant; freestone; not subject to curl leaf. September 1.

Salway. Fruit large, roundish; deep yellow, with a rich, marbled, brownish red cheek; flesh yellow, firm, juicy, rich and sugary. Tree exceedingly thrifty grower. Middle September.

ST. JOHN. Fully one week earlier than Early Crawford; a trifle smaller than the latter, especially old trees; yellow with deep red cheek; juicy, sweet and highly flavored; quite free. A splendid market fruit. Last of June.

Strawberry Free. Medium size, oval; stem cavity deeply sunk; suture extending half way round; skin almost wholly marbled with deep red; flesh whitish, juicy, rich and delicate. Early July.

Susquehanna. A large, handsome variety, nearly globular; skin rich yellow, with beautiful red cheek; flesh yellow, sweet, juicy, with a rich vinous flavor; strong grower. Middle of August.

Triumph. Good quality early peach; ripens just after Alexander; a favolite market variety. Middle June.

Wheatland. Large, roundish, skin golden yellow, shaded with crimson on the sunny side; flesh yellow, rather firm, juicy, sweet and of fine quality; tree vigorous; good for canning, drying or shipping. August.

\section{PEARS}

\begin{tabular}{|c|c|c|c|c|}
\hline & Each & $\begin{array}{r}\text { Per } \\
10\end{array}$ & $\begin{array}{l}\text { Per } \\
100\end{array}$ & $\begin{array}{c}\text { Per } \\
1000\end{array}$ \\
\hline Pear- & & & & \\
\hline 6 to $8 \mathrm{ft}$. & .......................... & 350 & 3500 & 30000 \\
\hline to & .......................... 35 & 300 & 3000 & 25000 \\
\hline to $4 \mathrm{ft}$. & 30 & 250 & 2000 & 17500 \\
\hline 2 to $3 \mathrm{ft}$. & .......................... 25 & 20 00 & 1600 & 12500 \\
\hline
\end{tabular}

BARTLETT. Large size, often with a beautiful blush next the sum; buttery, very juicy and highly flavored. Tree a strong grower, bearing early and abundantly; very popular. Best pear for California and only one of commercial importance at present. August.

Beurre Bosc. Large pyriform, a little uneven, skin pretty smoo'h, dark yellow, dots and streaks of cinnamon russet, slightly red on one side; flesh white. September.

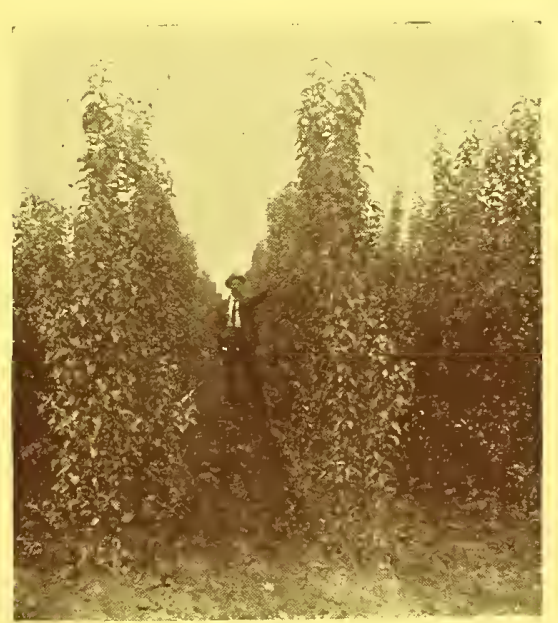

YEARLING BARTLETT PEAR ON JAP ROO'T

Beurre d'Anjou. A large, fine pear, buttery and melting, with sprightly, vinous flavor. Tree a fine grower and good bearer. October.

Beurre Hardy. Large; greenish, covered with light russet and shaded with brownish-red; flesh buttery, with a rich vinous brisk flavor. September.

Comice (Doyenne du Comice). A French pear of recent introduction and of much promise; fruit large; skin greenish yellow, shaded with crimson in sun; flesh buttery, rich and slightly aromatic. October.

Flemish Beauty. Large, pale yellow, marbled with light russet; flesh yellowish white, not fine grained but very juicy and melting; good bearer and very hardy. September and October.

Glou Morceau. Large, greenish yellow; flesh fine grained, melting, sugary. A good table pear and stands shipment well. December. 
Howell. Large, waxon yellow, sprinkled with minute russet dots; flesh whitish, juicy, brisk, vinous; vigorous grower and an immensely prolific bearer. August.

Madeline. Medium; pale, yellow, dotted with brown dots; flesh melting and juicy; the first early pear. June and July.

P. Barry. A most valuable winter pear, large to very large; ovate, pyriform; skin vellow, nearly covered with russet dots and blotches; flesh juicy, fine grained, flavor sprightly; vigorous grower and heavy bearer; excellent keeper. December to March.

Seckel. Rather small regularly formed, obovate; brownish green, becoming dull yellowish brown, with russet red cheek; flesh whitish, buttery, very juicy and melting, with peculiarly rich, spicy flavor and aroma. August to September.

Winter Bartlett. Fruit large, closely resembling the Bartlett in shape, appearance and quality, ripening three or four months later; remarkably productive. The best late pear.

WINTER NELLIS. Medium in size; yellowish green and russet; fine grained, melting, rich and delicate; one of the best of winter cears. Tree straggly, slender grower, but very productive. Particularly adapted to interior valleys of California. December.

\section{PLUMS AND PRUNES}

\section{PLUMS}

On Aimond. Peach and Myro.
$\begin{gathered}\text { Each } \\ \text { On }\end{gathered} \begin{array}{r}\text { Per } \\ \mathbf{1 0}\end{array}$

\section{PRUNES}

Each $\begin{gathered}\text { Per } \\ \mathbf{1 0}\end{gathered}$
$\begin{aligned} & \text { On Almond, Apricot, Myro. and Peach. } \\ & \mathbf{1 0 0}\end{aligned}$

Beauty. Large, early plum, of best quality. Good shipper. Before Climax.

Burbank. Very vigorous grower; early and very heavy bearer; fruit very large; yellowish ground, with red cheeks in the sun; flesh yellow, firm and very sweet when fully ripe; extremely small pit, which clings. Late June.

Climax. This is well named the "King of Plums," as its extreme earliness, immense size, high color, delicious flavor and fragrance place it in the lead among early shipping plums; fruit heart-shaped, color deep, dark red; flesh yellow. Tree vigorous grower and remarkably productive. Middle of June.
Clyman. Large, roundish, oblong, flattened; beautiful blue bloon; freestone; flesh firm, juicy and sweet, and of a slightly vinous flavor; good bearer; excel'ent shipper, and valuable mainly on account of its earliness. June 3 to 17 .

Damson (Shropshire). Snall, roundish oval; purple with thick blue bloom; melting, juicy, tart flavor; favorite for preserving. Late.

Diamond. Very large, oblong; dark purple with deep bloom; flesh yellow and of good quality; good shipper and quite profitable. July 15 to August 5.

Formosa. Very vigorous, upright grower with heavy, cherry-like foliage, affording ample protection to the fruit, which is of the largest size, heart-shaped and of a light cherry-red color; flesh pale yellow, usually firm, sweet, rich and delicious, with a delightful flavor. Before Climax.

French (Petite Prune d'Agen). Medium sized, egg-shaped, violet purple; flesh rich and very sweet; the variety most extensively used for drying. August to September.

Giant. Very large; flesh yellow, flavor good; freestone; fine market variety. Late August.

Grand Duke. Dark purple; flesh greenish yellow, with rich flavor; fine shipper. Late August.

Green Gage. Small; considered the standard of excellence. Middle of July.

Hungarian Prune (or Ponds' Seedling Plum). Very large; dark red; juicy and very sweet; its large size, bright color, productiveness and shipping qualities render it a profitable variety for home and distant market. August 15 to September.

Imperial. Large size; light or reddish purple color; thin skin; sweet and high flavored; tree stout, stock and rapid grower. August and September.

Jefferson. Large, oval, base slightly narrowed; greenish yellow, becoming golden, with reddish cheek; bloom thin, white; flesh rich yellow, juicy, high-flavored and luscious; adheres partly to its long-pointed stone; a slow grower but productive.

Kelsey. Very large, heart-shaped; greenish yellow overspread with bright red when fully ripe; covered with bloom; flesh yellow, firm, clings slightly; tree prolific and early bearel. Largely planted for shipping east and also valuable for domestic use. July to September.

Shiro. J. Originated by Luther Burbank. Fruit egg-shaped, large size, smooth, bright yellow, thin bloom; flesh elings to the pit. Very prolific. 
Gaviota. Ripens two weeks after Formosa; is of a deep reddish purple color; flesh honey-yellow; fragrant and sweet to the pit, which is so small in comparison with size of fruit that it might almost be called "seedless." July.

Prunus Simoni (Apricot Plum). A distinct species from China. Growth erect, flowers small, white, appearing in the spring; fruit large, flattened and of the size and appearance of a nectarine and of a brick-red color; flesh yellow with a peculiar aromati flavor.

$\checkmark$ Red June. Medium to large; deep vermillion red, with handsome bloom; flesh light lemon yellow, firm, moderately juicy, fine quality; tree upright, spreading, vigorous and hardy; productive. Very early.

Robe de Sargent. Fruit medium large, oval; skin deep purple approaching to black and covered with a thick blue bloom; flesh greenish yellow, sweet and well flavored, sugary, rich and delicious, adhering slightly to stone. This variety makes a large, darker colored dried prune than the French prune and is valuable both for drying and shipping. Coming into increased favor every year in the interior valleys of California. August and September.

Santa Rosa. Very large; deep crimson, with pale blue bloom; flesh near skin is purple, toward pit is amber colored; pit is very small; tree is extremely vigorous grower, regular and heavy bearer. The splendid appearance of the fruit makes it a valuable shipper. With Climax.

Satsuma (Blood Plum). Native of Japan; fruit has a pleasant flavor, and unlike all other varieties has red flesh, with a remarkably small pit. July to September.

Silver Prune. Said to be a seedling of Coe's Golden Drop, but undoubtedly one and the same; fruit of the largest size, skin pale yellow; profitable as a bleached prune and for canning. September.

Standard. Fine drying or shipping prune; cross between Tragedy and Sugar. August to September. Earlier than French.

Sugar. Originated by Luther Burbank. Ripens 28 days earlier than the French; large and has high sugar content; most valuable as a shipping prune, but is dried to some extent; dark purple with thick, white bloom; freestone. Early August.

Tragedy. Medium size; dark purple; flesh yellowish green, rich and sweet; tree vigorous grower and good producer; valuable as early shipper. Late June.

Vesuvius (Foliage Plum.) Chiefly valued for the unusual color of its leaves, being blood red; the fruit is of a good quality and can be used for all purposes.

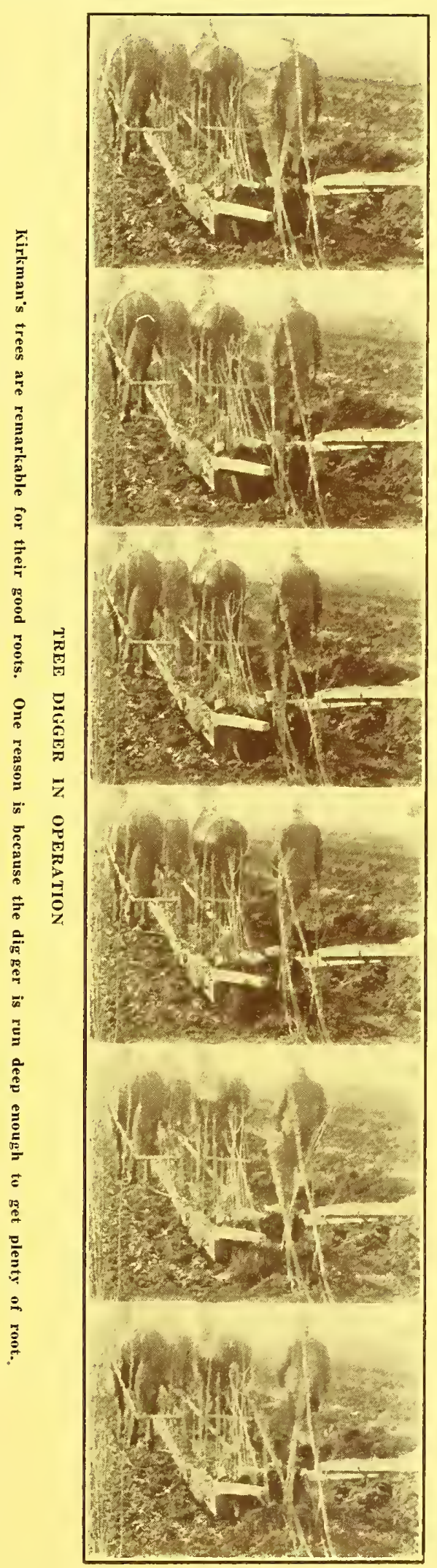




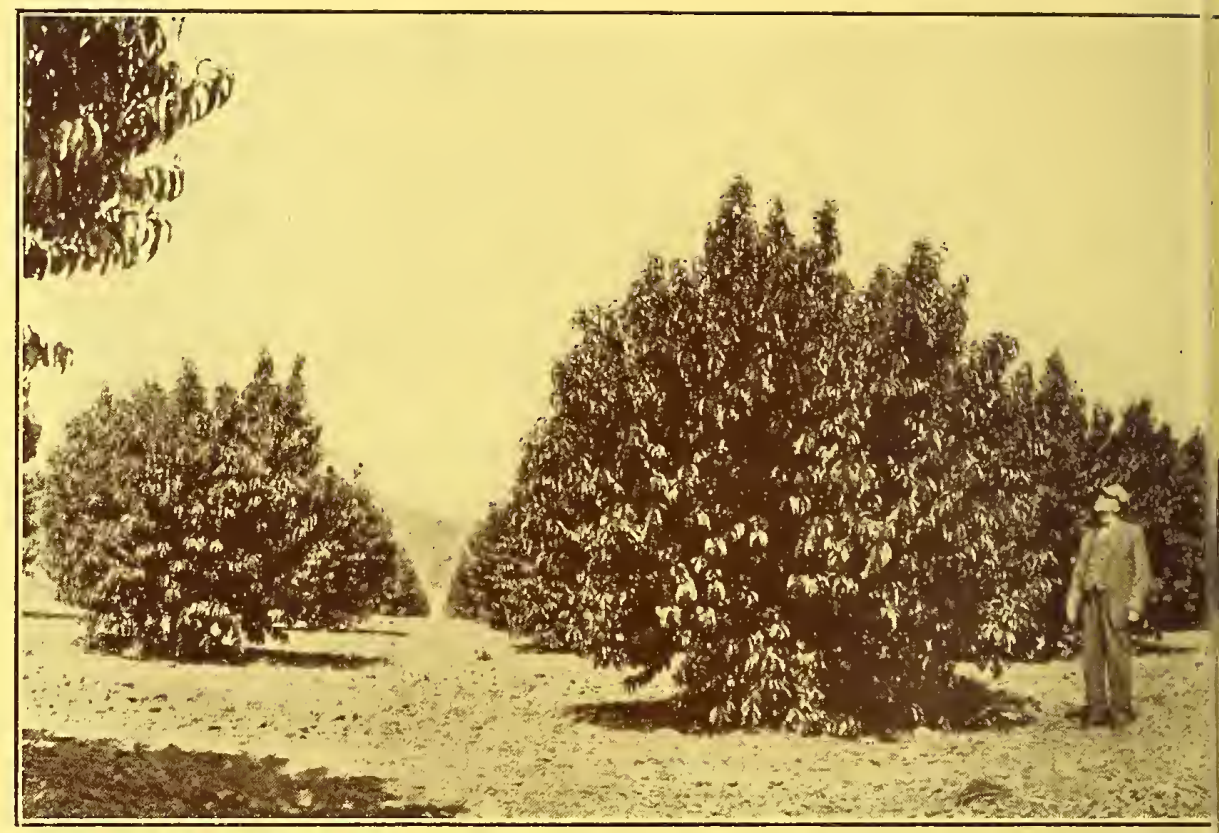

LOVELL PEACH TREES PLANTED DURING THF

There are over 2000 acres of Kirkman Trees in this orchard. Note the uniformity of growth he this orcliard in the an

Wickson. A sturdy, upright grower; productive; fruit remarkably handsome, deep maroon-red; covered with white bloom; stone small; flesh fine texture, firm, sugary and delicious; excellent keeper and shipper. July.

$\checkmark$ Yellow Egg. Very large and beautiful eggshaped yellow plum; a little coarse, but excellent for cooking; tree a free grower and very productive. July and August.

\section{PECANS}

PECAN-Grafted.

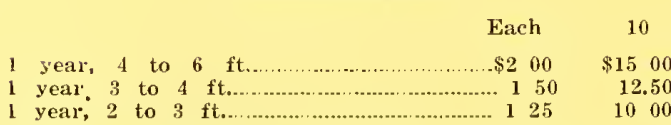

Stuart. Large, well-shaped nut, fills well, splendid flavor. Probably best for orchard planting in the valley.

$\checkmark$ Success. Very large, thin shell, plump kernel.

Van Deman. Paper shell, large, oblong nut of first quality.

\section{PERSIMMONS}

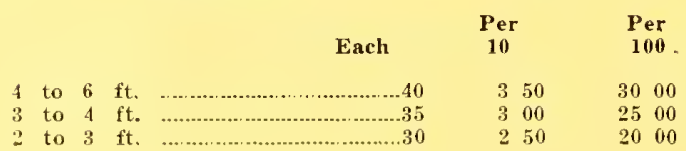

Hachiya. Fruit very large, oblong, conical, pointed toward the apex, skin bright red, with occasional dark spots or blotches near the apex; flesh deep yellow, soft and jellylike when ripe; seeds usually absent. A valuable variety, considered to be one of the best, and earliest. October.

Hyakume Persimmon. Averaging 3 inches in diameter and 5 ounces in weight. Skin yellow; flesh dark brown. Jelly, sweet and not astringent; few seeds. Keeps very late. Tree of moderate height; often of dwarf growth. October.

Mammonith Goshio. Highly recommended from JJapan. A new production and said to be the best. An improvement on Goshio, but as its name implies, much larger than Goshio, averaging to a larger size than any other variety.

Tane-Nashi. Very large and smooth; bright red; flesh yellow; seedless. Tree vigorous, bearing well. September.

\section{QUINCES}

On Quince.

$\begin{array}{ccc} & \text { Per } & \text { Per } \\ \text { Each } & 10 & 100\end{array}$

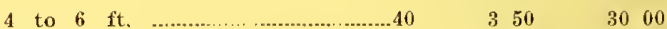

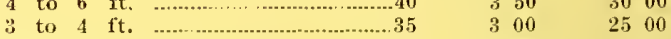

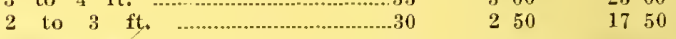

Apple or Orange. Large; fine golden color; valuable for preserves or flavoring. September. 


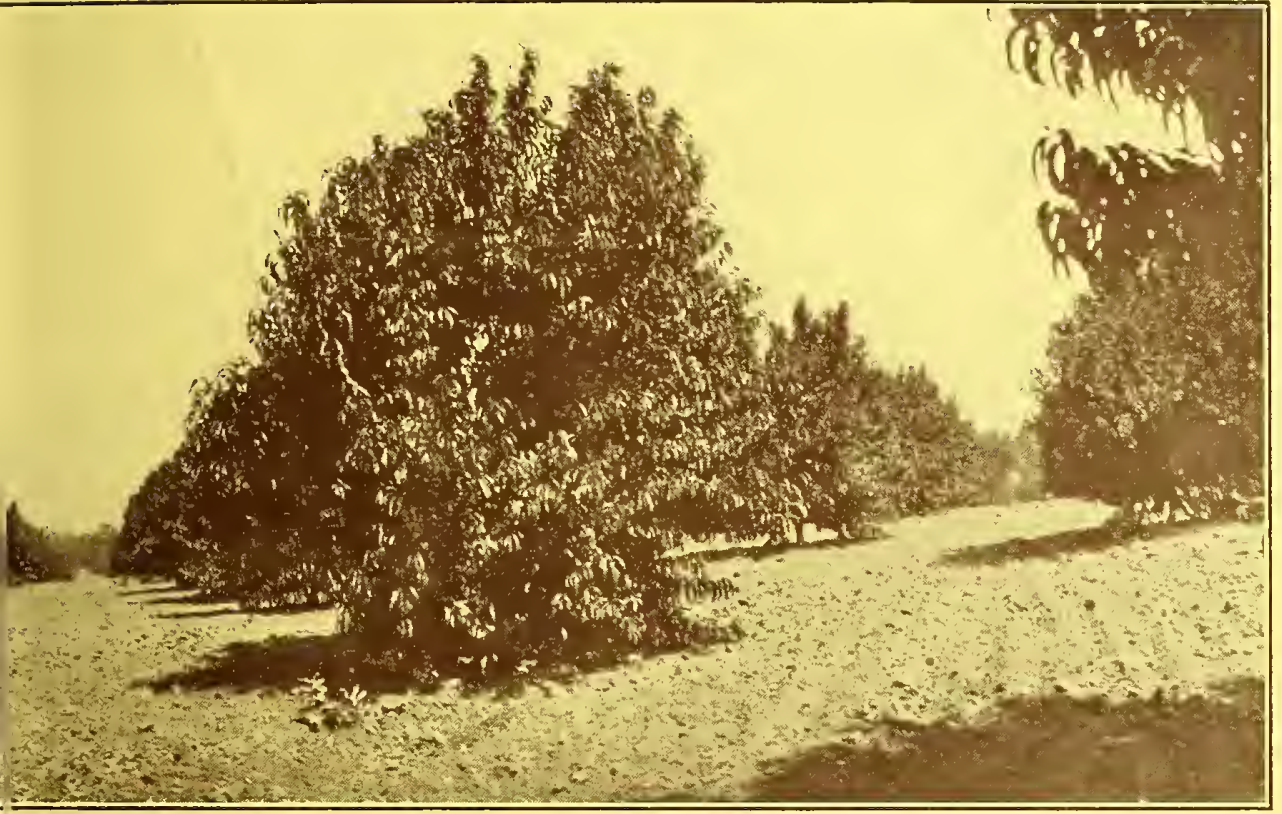

G OF 1915. PHOTO TAKEN IN SUMMER OF 1918

ure in the foreground is the universally admired Prof. E. J. Wickson, who keeps a fatherly eye on $t$ of advisory horticulturist

Champion. Ver'y large; lively yellow; cooks very tender. Late September.

Pineapple. Originated by Luther Burbank; flavor suggestive of the pineapple; makes a superior jelly; can be eaten raw and will cook as tender in five minutes as the best cooking apples.

$\checkmark$ Rea's Mammonth. Large; bright yellow; a strong grower and very productive. October.

Smyrna. Extremely large, elongated, lemonyellow; cooks tender and has a fine flavor; long keeping; tree strong grower; very prolific, ripening with Orange. One of the best.

\section{WALNUTS}

\begin{tabular}{|c|c|c|c|c|c|c|}
\hline & & & Each & $\begin{array}{r}\text { Per } \\
10\end{array}$ & $\begin{array}{l}\text { Per } \\
100\end{array}$ & $\begin{array}{c}\text { Per } \\
1000\end{array}$ \\
\hline & 10 & $\mathrm{ft}$. & 15 & 1500 & 12500 & 一. \\
\hline 6 & to & ft. & ......... 50 & 1250 & 10000 & $900 \quad 00$ \\
\hline 4 & to & $\mathrm{ft}$. & $\ldots$ & 1000 & 8500 & $750 \quad 00$ \\
\hline $\overrightarrow{4}$ & to & ft. & 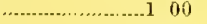 & 750 & 7000 & 60000 \\
\hline
\end{tabular}

EUREKA. The trees are upright, vigorous growers, with clean branches and open growth; bark sliglitly rough and not subject to sunburn; the most resistent to blight known at present, and one of the best producers; specially desirable in lo- calities having late frosts, being a late bloomer and ripening about ten days later than the average; nuts large, soft-shelled, elongated, smooth and tightly sealed.

FRANQUETTE. Tree very hardy, clean, vigorous grower; very late bloomer and a regular and prolific bearer; nuts large, of medium size, long and smooth, medium thick shell; kernel full, sweet and of rich, nutty flavor.

MAYET'TE. Large, well shaped, with board base; shell light colored, thin; kernel full and rich. Late bloomer and abundant bearer. This variety is regarded as the most valuable variety by many growers.

Wilson's Wonder. A strong, sturdy grower, with broad, dark green leaves. The nut is abnormally large, with thin, smooth, perfectly sealed shell, well filled with exceedingly rich, sweet kernel. It blooms and puts out foliage later than the common sorts, avoiding late spring frosts. 



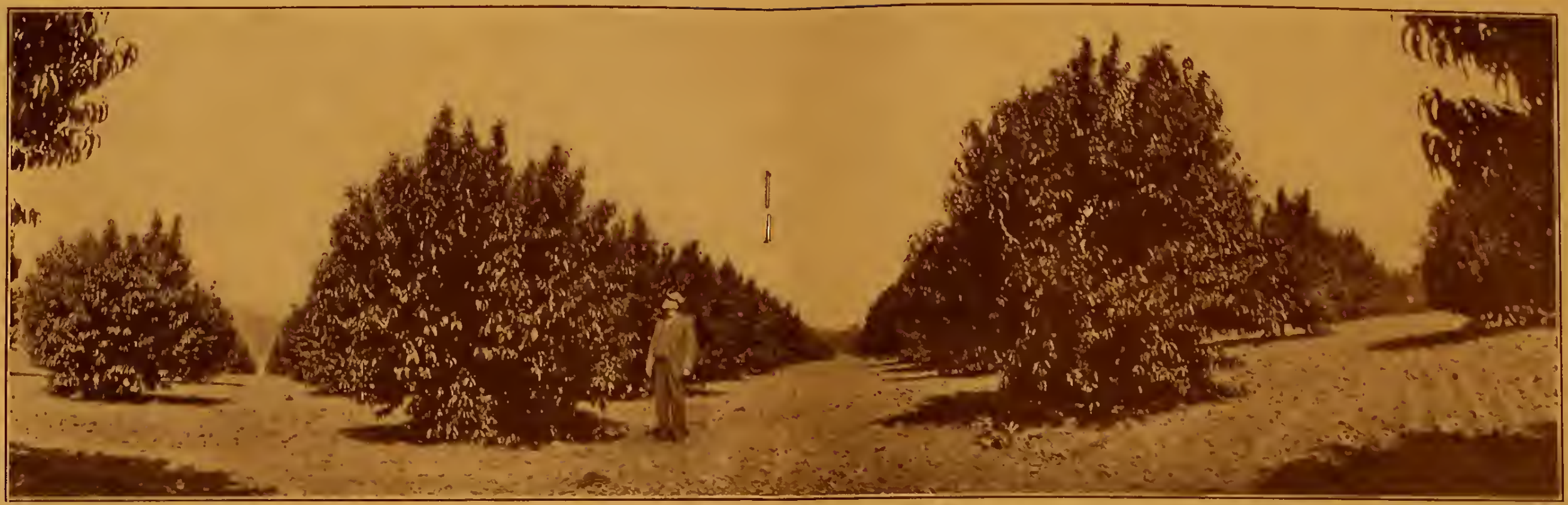

LOVELL PEACH TREES P'LANTED DURING THE SPRING OF 1915. PHOTO TAKEN IN SUMMER OF 1918

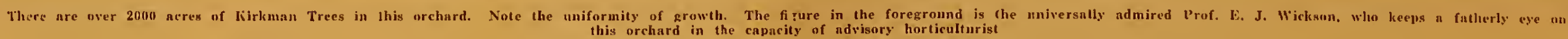

Wickson. A sturdy, upright grower; producroon-red; covered with white bloom; ston small; flesh fine texture, firm, sugary an delicions; excellent keeper and shipper. July.

Yellow Egg. Very large and beautiful eggshaped yellow plum; a little coarse, but exvery productive. July and August.

\section{PECANS}

PECAN-Grafted.

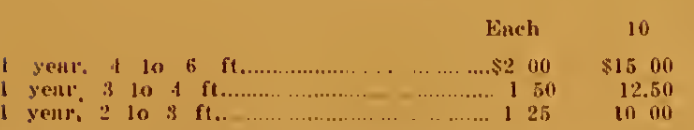

stuart. Large, well-shaped nut, tills well, splendid flavor. Probably best for orchar

Success. Very large, thin shell, plump kernel.

Van Denan. Paper shell, large, oblong nut of first quality.

PERSIMMONS

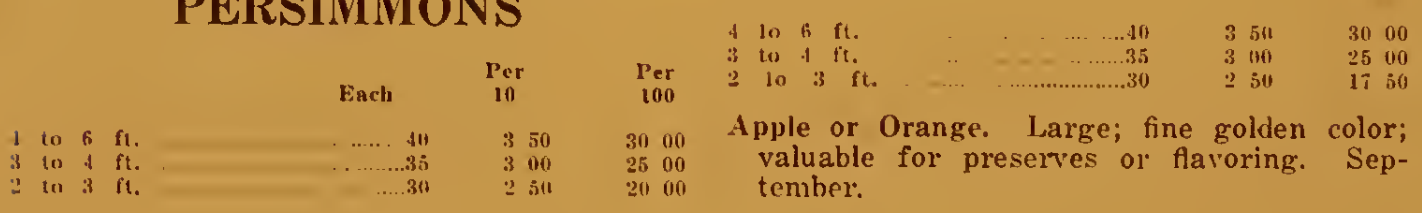

Hakume Persimmon. Averaging 3 inches in diameter and 5 ounces in weight. Skin yellow; flesh dark brown. Jelly, sweet and not astringent; few seeds. Keeps very late. Tree of moderate height; often

Mammorth Goshio. Highly recommended from Japan. A new production and said to be the best. An improvement on Goshio, but as its name implies, much larger than Goshio, averaging to a larger size than any other variety.

Tane-Nashi. Very large and smooth; bright bearing well. September.

\section{QUINCES}

O) Quine.e.

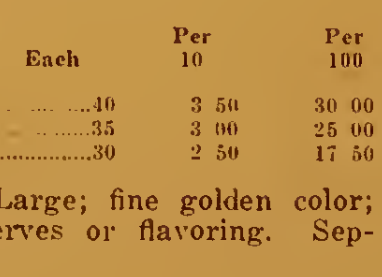

Chanpion. Very large; lively yellow; cooks very tender. Late September.

Pineapple. Originated by Luther Burbank; flavor suggestive of the pineapple; makes a superior jelly; can be eaten raw and will cook as tender in five minutes as the best cooking apples.

calities having late lrosts, being a late bloomer and ripening about ten diyys later than the average'; unts laree, softesilelled, elongated, smooth and tightly sealecl.

FRANQUETTE. 'Tree' very hardy, clean, vigorous grower; very late hlooner and a regular and prolitic besirer; nuts large, of medium si\%, long and smooth, medlinn thick shell; kerruel full, sweet and of rich, nulty flavor.

Rea's Mammonth. Large; bright yellow; strong

tober.

Smyrna. Extremely large, elongater, lemonyellow; cooks tender and has a fine flavol; long keeping; tree strong grower; very prolific, ripening with Orange. One of the best.

\section{WALNUTS}

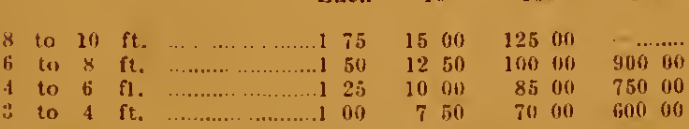

EUREKA. The trees are upright, vigorous growers, with clean branches and open growth; bark slightly rough and not subject to sunhurn; the most resistent to blight known at present, and one of the hest producers; specially desirahle in 10-
MUET'E Large, well slaperd, with hoard base; shell light colored, thin; kernel full and rich. Late hloomer and ahumdant hearer. This variety is regarded as the most valuable variety by inany growers.

Wilson's Wonder. A strong, sturdy growere, with broar, dark green leaves. The nut is abnormally large, with thin, sinooth, perceedingly rich, sweet kernel. it blooms mon sorts, uvoiding late spring frosts. fectly sealesl shell, well fillerl with exand puts out foliage later than the com- 


\section{CITRUS FRUITS}

\section{ORANGES}

(Washington Navel, Valencia)

On Swcet and Sour Roots:

Each $10 \quad 100 \quad 1000$

$\begin{array}{lcccccccccc}1 & \text { inch and up............. } \$ 1 & 50 & 12 & 50 & \$ 120 & 00 & \$ 1100 & 00 \\ 3 / 4 & \text { to } 1 & \text { inch, caliper.... } & 1 & 35 & 12 & 00 & 110 & 00 & 1000 & 00\end{array}$

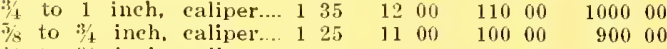

$1 / 2$ to $\%$ inch, caliper.... $110 \quad 1000 \quad 9000 \quad 80000$

\section{TANGERINES, LIMES, KUMQUATS}

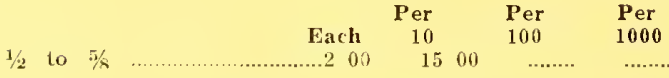

\section{LEMONS}

On Sweet and Sour Roots:

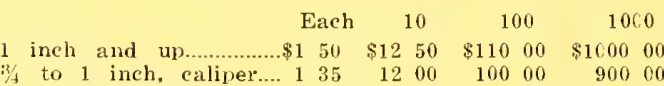

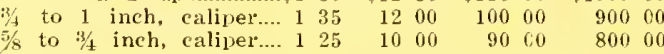

Eureka. The most popular variety in California. Fruit is of highest quality, uniform size, with few seeds. Rind smooth and glossy. Tree is vigorous grower, almost thornless. A prolific bearer throughout the year, the summer crop being particularly valuable.

Lisbon. Fruit juicy, strong acid flavol, few seeds; of fine texture and a good shipper. Tree strong glower, branches thorny, foliage heavy; very prolific bearer.

Seedless Eureka. A new variety resembling the Eureka in every respect except that nearly every fruit is entirely seedless.
Tree a good strong grower and bears uniformly heavy crops. Some lemon growers who have observed this variety in bearing see a bright future for it and are planting several acres to it.

Villa Franca. A fine variety and valuable for commercial planting. Fruit oblong; rind thin, without trace of bitterness. Pulp acid, juicy, nearly seedless. Tree thornless, of spreading habit. Will stand lower temperature than any other lemon.

\section{- KUMQUATS}

A dwarf, hardy tree; golden yellow fruit, palatable either fresh or preserved. Fruit size of large gooseberry. Tree very handsom for indoor growing.

Tangerine (Dancy). Fruit medium size; pulp very sweet; rind thin, separates easily. March.

\section{LIMES}

Bearss Seedless. Very large; seedless; very juicy, with pronounced acidity. One of the best in cultivation. Hardy, enormously productive and matures fruit year round.

\section{POMELOS}

$\begin{array}{llll}\text { Each } & 10 & 100 & 1000\end{array}$ 1 inch and up.............. \$1 $50 \quad \$ 12 \quad 50 . \$ 120 \quad 00 \$ 1100 \quad 00$ $3 / 4$ to 1 inch, caliper.... $1355 \quad 1200 \quad 11000 \quad 1000.00$ $5 / \%$ to $3 / 4$ inch, caliper... $125 \quad 1100 \quad 100 \quad 00-900 \quad 00$

Marsh's Seedless. Practically free from seeds; large, round, juicy; rind thin, lemon yellow; flavor full and rich, and pleasant to every taste. By far the best Pomelo. 


\section{OLIVES}

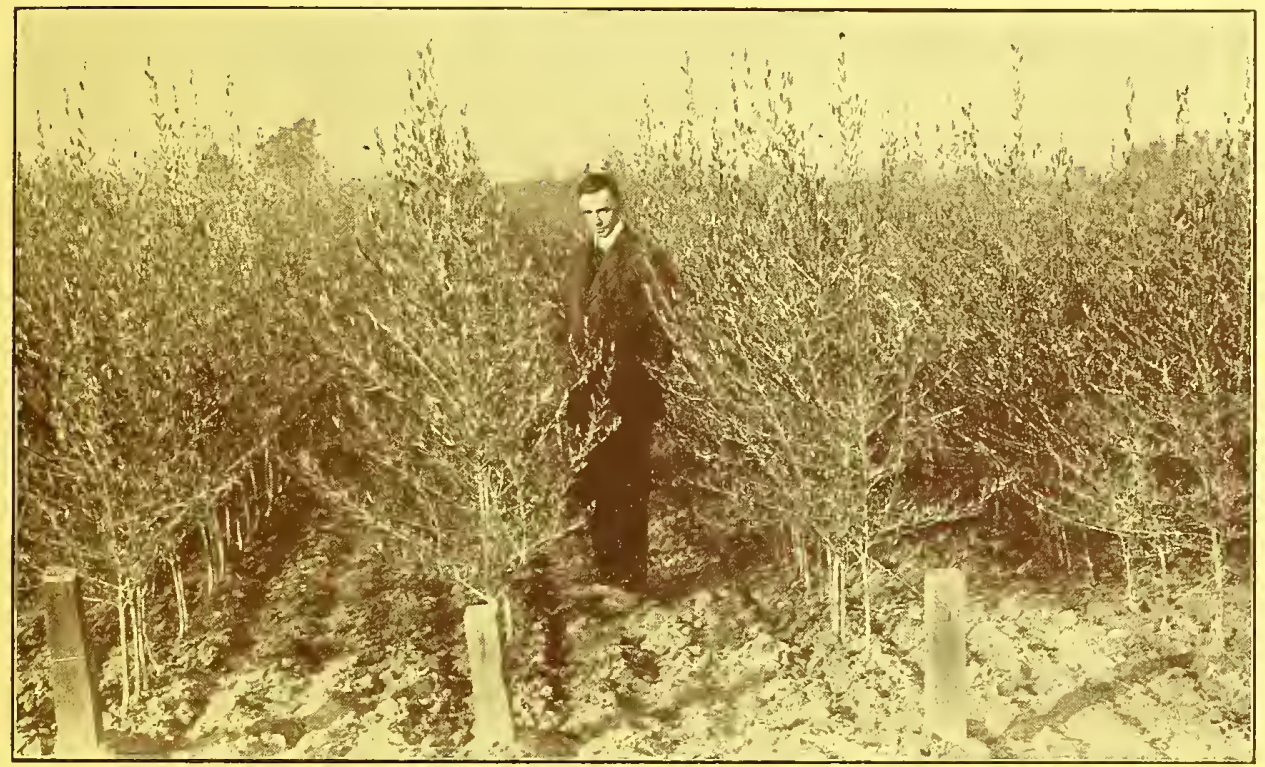

TWO-YEAR-OLD MISSION OLIVE TREES.

\begin{tabular}{|c|c|c|c|c|}
\hline & & Per & $\mathbf{P} 2 \mathbf{r}$ & Per \\
\hline & Each & 10 & 100 & 1000 \\
\hline in. and up & .100 & 750 & 6000 & $550 \quad 00$ \\
\hline 1 to 1 in. caliper........... & 70 & 600 & 5000 & $450 \quad 00$ \\
\hline $\mathrm{s} / \mathrm{s}$ to $\mathrm{z} / \mathrm{s}$ in. caliper................ & 60 & 500 & 4000 & 35000 \\
\hline 2 to $\%$ in. caliper........ & . 45 & 400 & 3500 & 30000 \\
\hline
\end{tabular}

$\checkmark$ MISSION. An old standard sort, introduced by the Spanish Padres. Extensively cultivated. Fruit medium to large, making an excellent pickle either green or ripe as well as a superlative oil. Tree is very vigorous, upright grower, surpassing all other varieties in this respect. Thrives everywhere, being a regular and heavy bearer. November.
OTE THE STRAIGHT, THRIF'TY TREES

MANZANILLO. This variety is considered to be in the front rank as a pickling olive and is also a good oil olive. Tree is free grower and bears heavily of large sized fruit. Ripens two weeks before the Misson.

Ascolano. A fine Italian olive. Fruit large and fine, exceeding in size but having less flavor than the Manzanillo or Mission. Of light color' and fine appearance.

Sevillano. The largest olive, known as Queen Olive of commerce. Only fit for green pickles. Large size and early ripening make it valuable. Early October. 
The only variety we are offering this sea son is the:

\section{FUERTE AVOCADO}

A tropical or sub-tropical pear-shaped or spherical fruit, of great food value, which will undoubtedly become one of the leading commercial fruits of California, as all who have tested it so far are enthusiastic in its praise as an income producer.

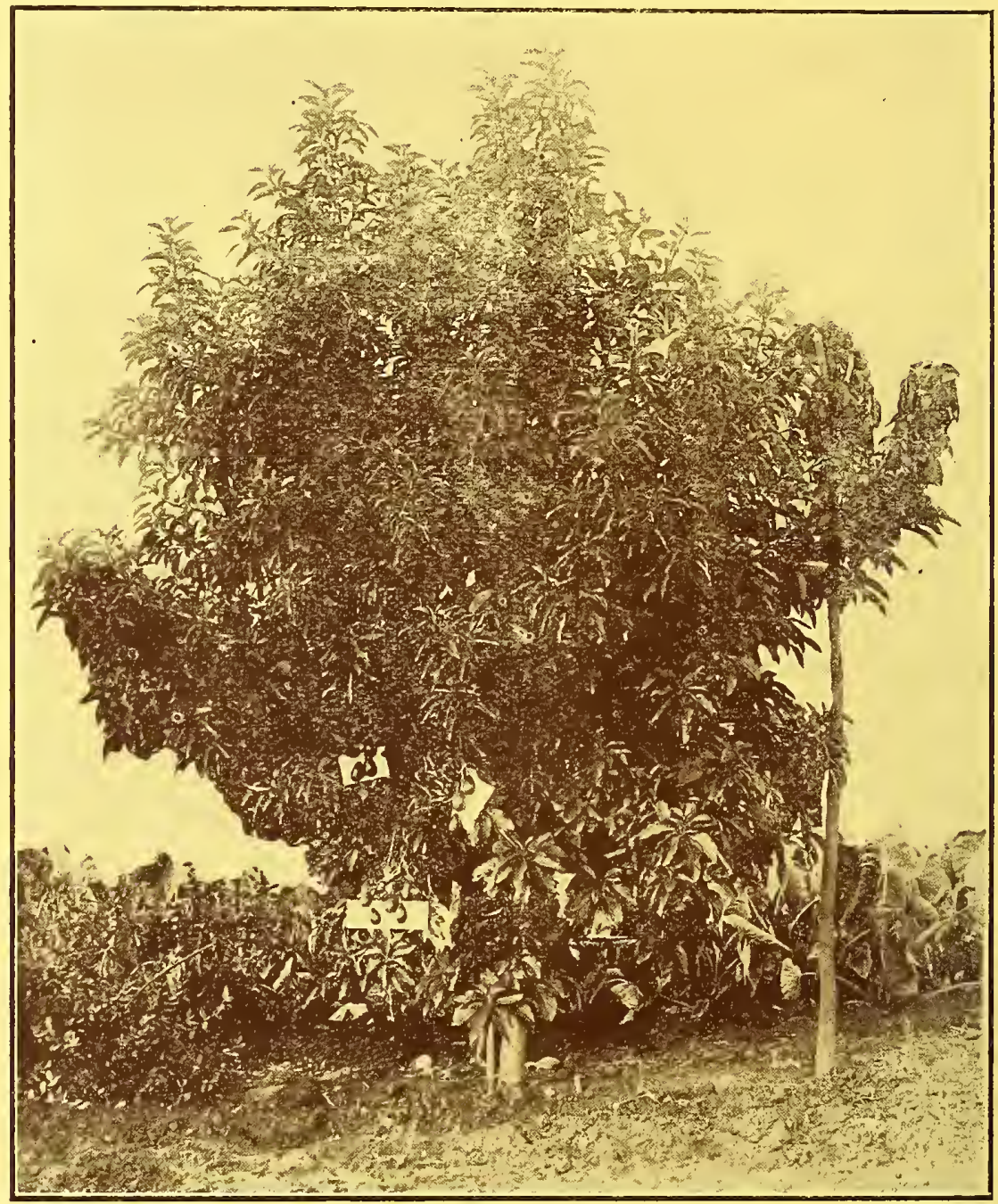

Three-year-old Avocado on Kirkman Nursery property at "Avocado" Station, Fresno County. These trees call be grown successfully only in Thermal locations. They can be grown where lemons are uninjured by frost.

This new variety has been thoroughly tried out and shows the following desirable characteristics:

Vigor of growth:-Out ranks all other types introduced to this state.

Hardiness:--Equal to any of the Mexican sorts in resisting both frost and hot weather.

Early Production:-Begins to bear in second or third year.

Heavy Yield:-Promises to equal any other variety.

The Fuerte is a good sized Avocado, weighing about one pound, with small seed and skin sufficiently tough for protection in shipping. The color is purple, the quality of the best. It ripens in January, February and March, the most desirable season for marketing, but the fruit can be left on the tree until summer without deterioration. 
We have a report from one lot of 50 trees which yielded $\$ 12.00$ per tree in the third year, $\$ 60.00$ per tree in the fifth year $\$(300.00$ from the acre of ground in the fifth season )

Pric $\rho$ of field grown trees budded on hardy Mexican roots, balled or established in 5 gallon cans:

3 to $4 \mathrm{ft}$.

$\begin{array}{ccc}\text { Each } & 10 & 100 \\ 400 & 3750 & 35000\end{array}$

\section{AVDCADO (ALLIGATOR PEAR)}

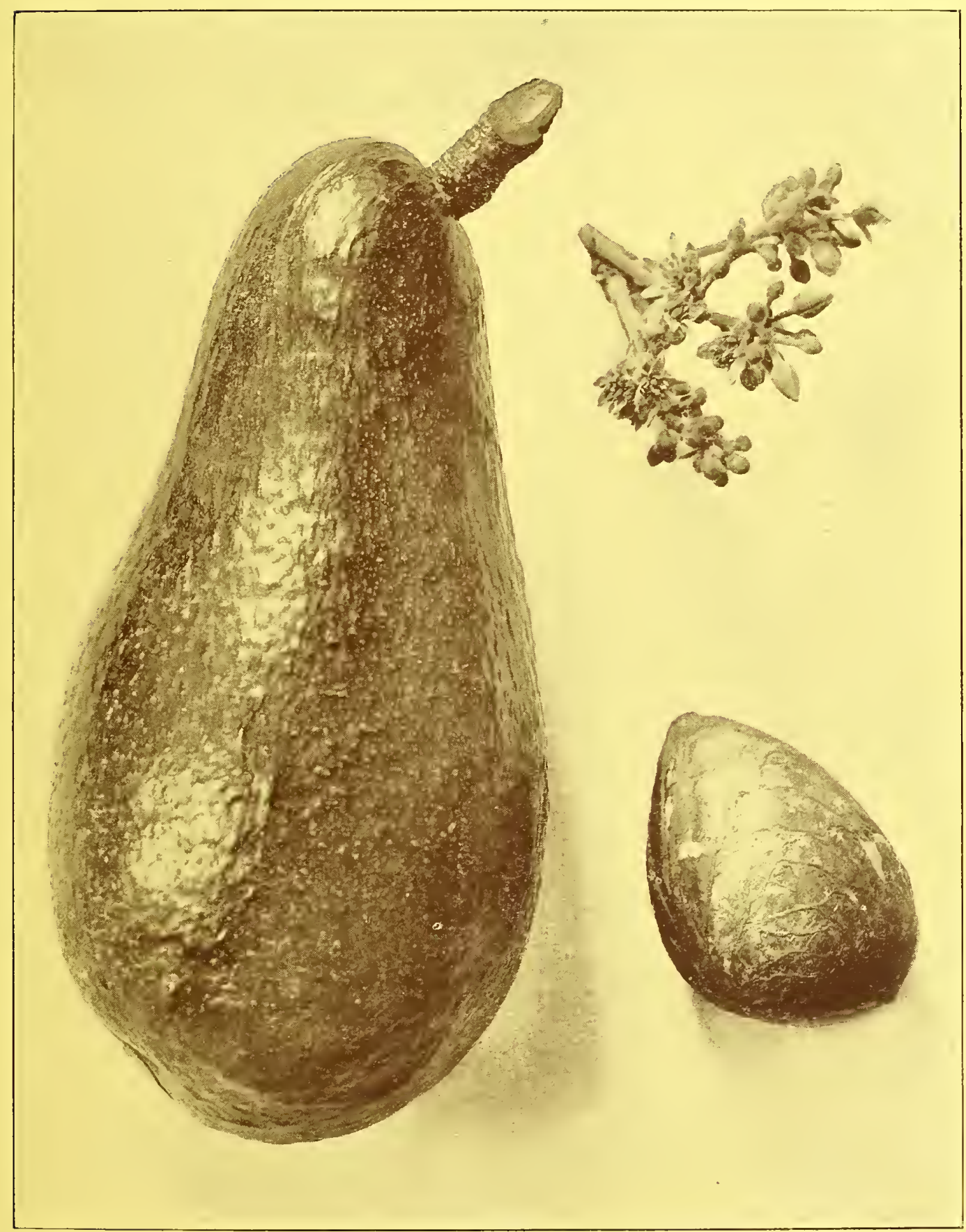




\section{GRAPES AND SMALL FRUITS}

\section{GUAVAS}

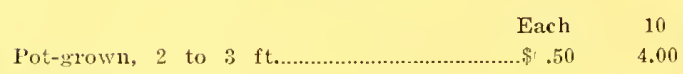

Lemon Guava. Grows to be a large shrub. Should be planted only in favored localities as it is somewhat tender; fruit pear-shaped, yellowish; highly prized for jellies and, jams.

Strawberry Guava. Shrub or small tree, producing fruit of a fine deep claret color, with strawberry-like flavor.

\section{LOQUATS}

Fach

3 to $4 \mathrm{ft}$

$\$ 200$

2 to $3 \mathrm{ft}$.

150

$\checkmark$ Advance. An cxcellent varicty with a fine flavor.

$\checkmark$ Champagne, Premicr.

\section{POMEGRANATES}

\begin{tabular}{|c|c|c|c|c|}
\hline & & Each & 10 & 100 \\
\hline to & & 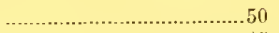 & 450 & \\
\hline to & ft. & 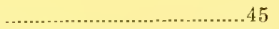 & 400 & \\
\hline to 3 & ft. & 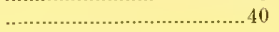 & 350 & \\
\hline
\end{tabular}

Paper shell. of large size and fine quality. Thin skin, colored pale yellow and crimson.

Wonderful. Of large size, rich coloring and excellent flavor. Ripens late and is valued for shipment.

\section{GRAPES}

GRAPE VINES

\section{RAISIN GRAPES}

MUSCAT. Bunches long and loose shouldered; berry oval, sometimes round; yellowish green skin; flavor strong and characteristic. Most extensively planted variety for raisins.

SULTANA SEEDLESS. Berries small, round, firm and crisp; golden yellow and seedless; bunches very large and long. Vine vigorous and prolific. Largely planted for seedless raisins and table fruit. Early.

THOMPSON SEEDLESS. Oval, greenish yellow berries, as large or larger than Sultana; seedless, thin skinred, good flavor; vine strong grower and unusually. heavy bearer. Bunches very large. Valuable for either shipping or seedless raisins. Ripens early, before Sultara.

\section{TABLE AND SHIPPING GRAPES}

CORNICHON. Bunches long and loose; berries oval; skin thick, covered with bloom; firm, good quality; one of the best late shippers.

EMPEROR. Bunches large, long and rather loose; berry large, oblate, wine colored, very firm; very late and in front rank as a shipping grape.

MALAGA. Vine a strong grower and immensely productive, thriving in almost any soil. Bunches very large, oval, yellowish green; skin thick, fleshy. Makes a second quality raisin. One of the very best shipping grapes, commanding good prices every season. 


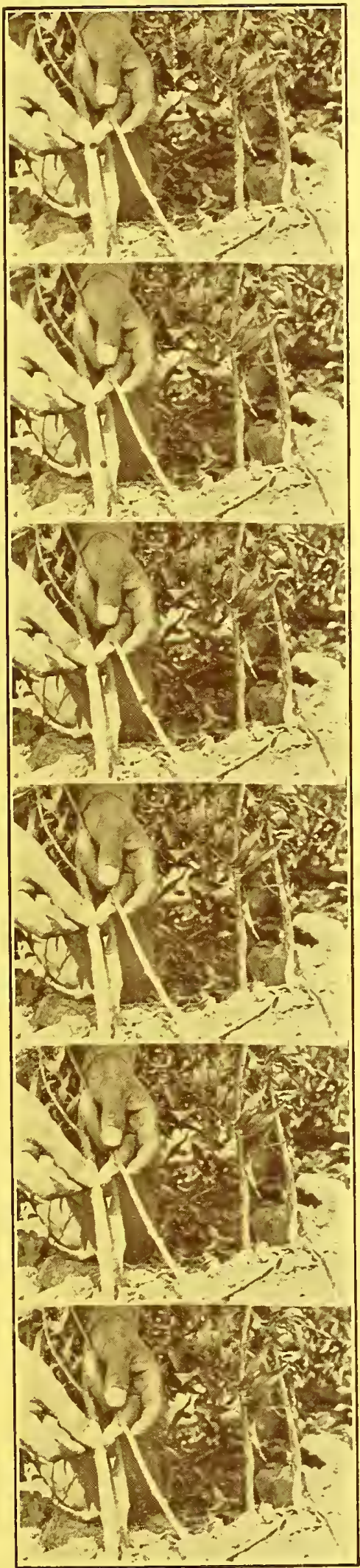

As stated in the title page we are not now growing Shade Trees nor Ornamental Nurscry Stock.

It is not our intention to revive the growing of these varieties as we are planning to increase our present large output of Fruit Trces and Vines.

We hope to grow enough of these Standard Varieties in high class stock to supply all business that is offered us.

Prospective planters are invited to visit us and inspect our growing stock.

KIRKMAN NURSERIES.

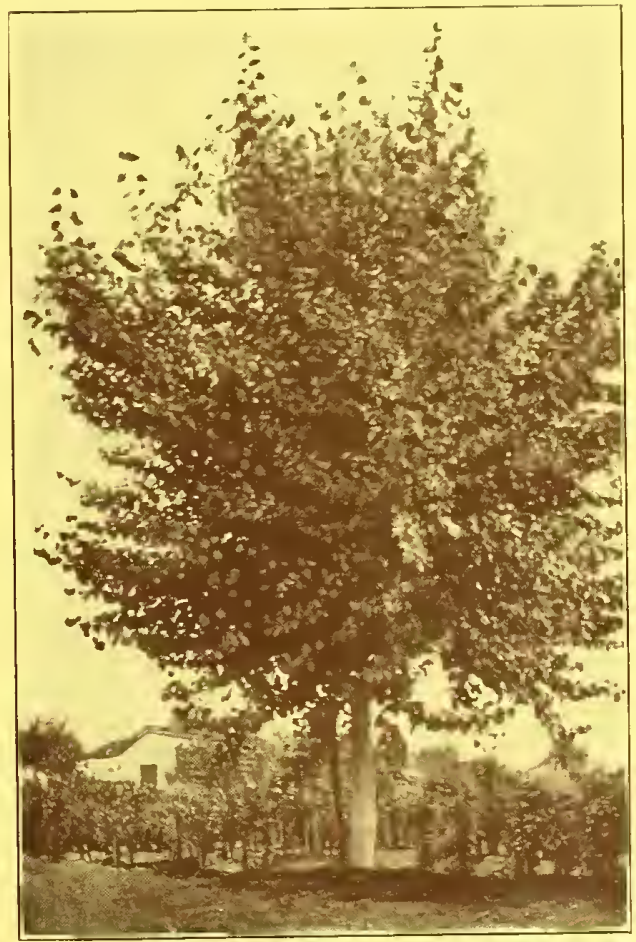

THREF YEAR OLD BALM OF GILIAD (Western)

Fine for wind breaks or quick shade.

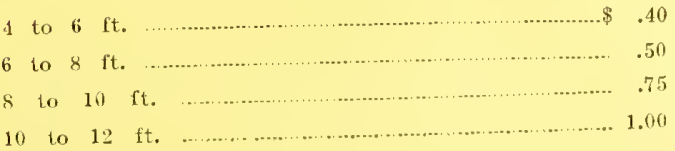




\section{INSTRUCTIONS}

All prices herein, are for delivery f. o. b. Fresno, or at our Nursery Plants in Madera, Merced, Sacramento and Los Angeles Counties with an additional charge to cover the cost of packing materials used.

Customers will be accorded the thousand rate where three hundred or more of one class of trees are ordered, as for instance, peaches or apricots or almonds. Fifty or more will be given the hundred rate, and five or more the ten rate.

\section{GUARANTEE}

We are always glad to rectify any mistakes that we may make in filling orders, but request that customer's call them to our attention immediately on receipt of the shipment.

In growing and furnishing nursery stock we exercise the greatest care in keeping our varieties true to name. We will replace any that may prove untrue, but in no case are we to be held liable for more than the purchase price.

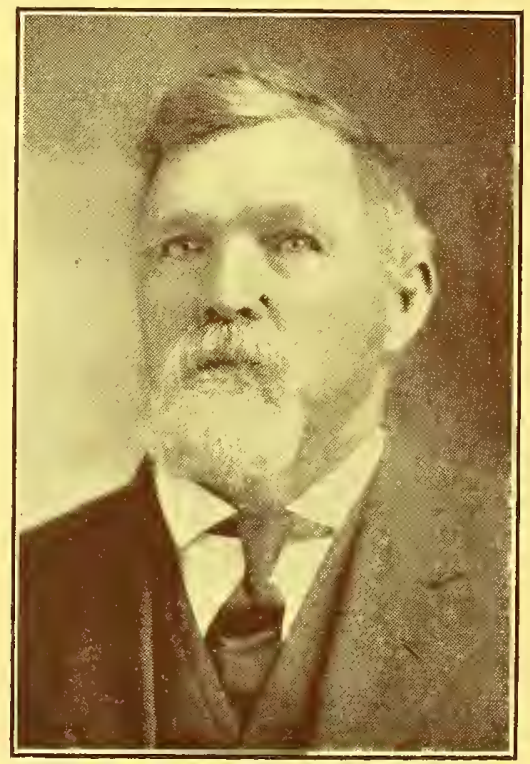

W. 'T. KIRKMAN, SR.

On the job for nearly fifty years. Southern California planters may get in touch with him at his home, 1075 Topeka St., Pasadena, Cal. 


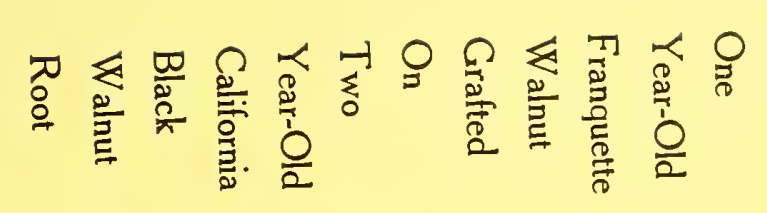

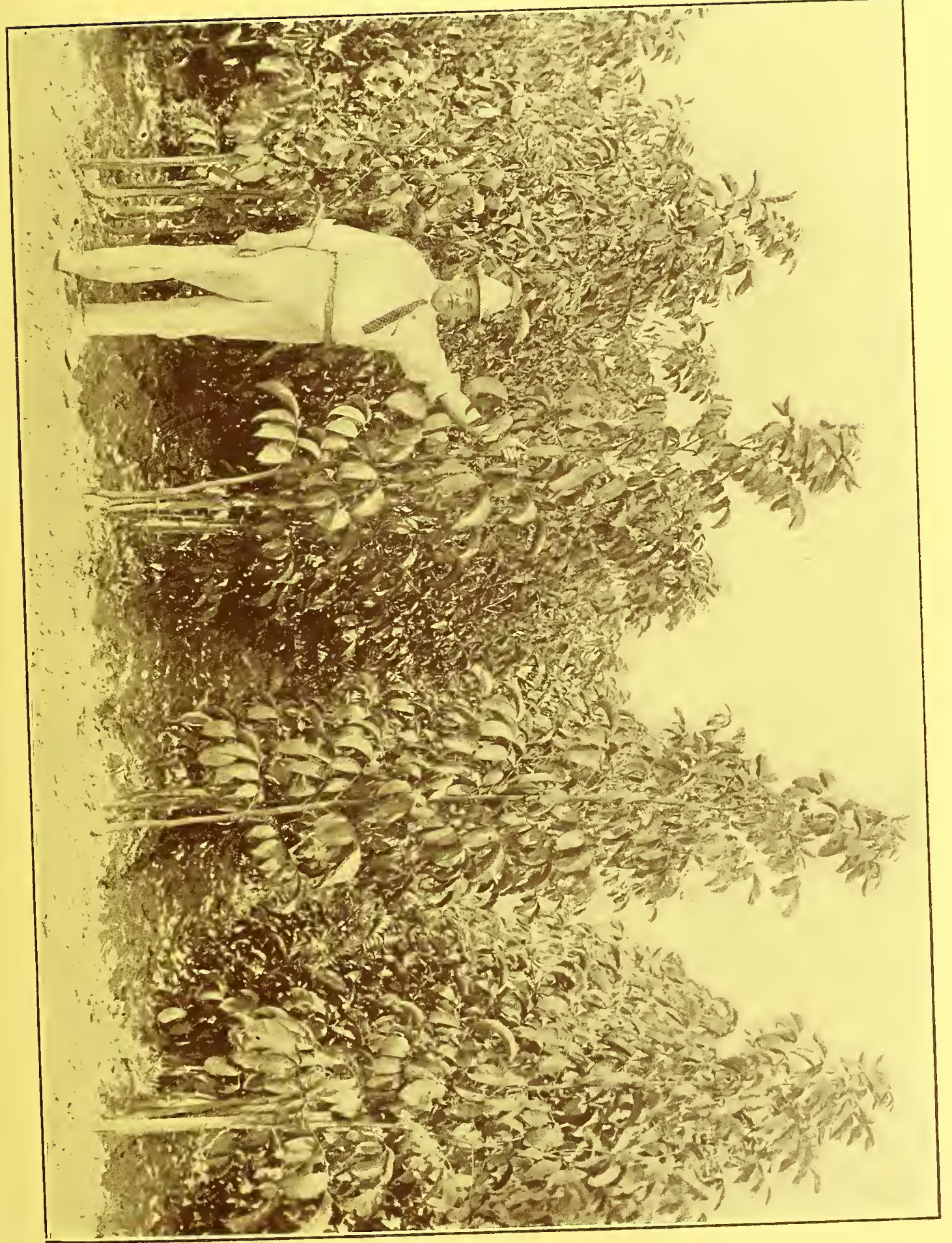




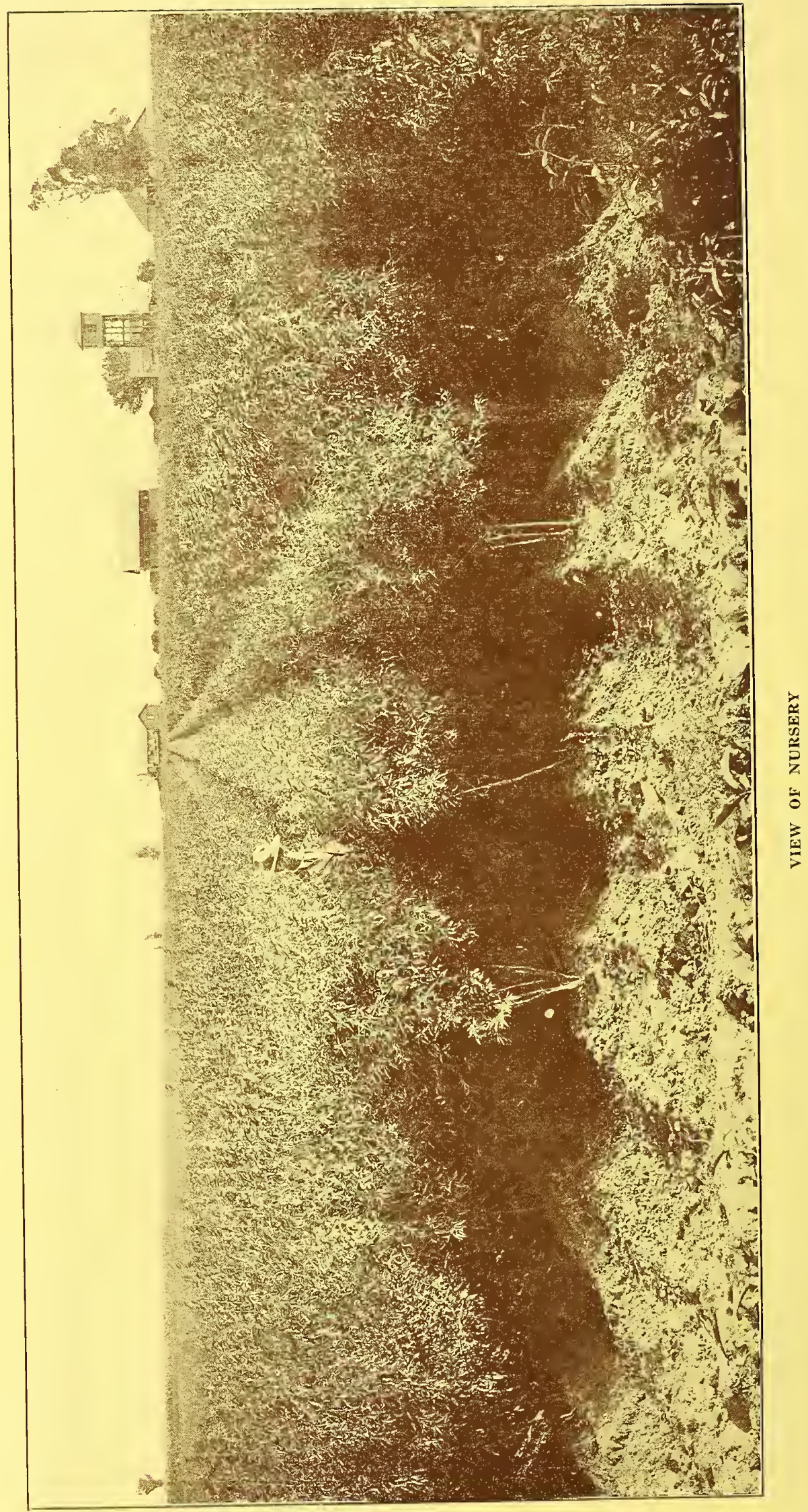






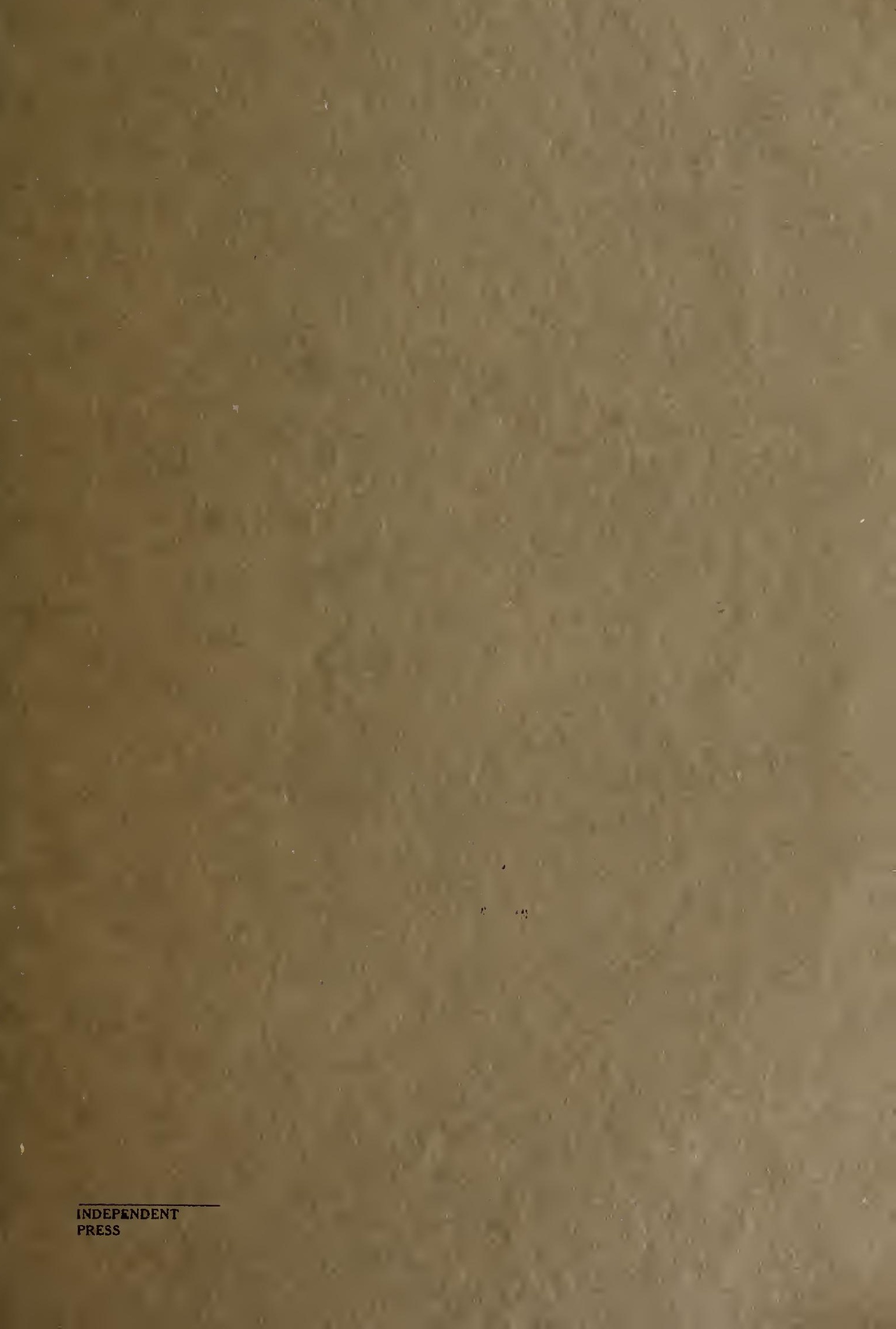




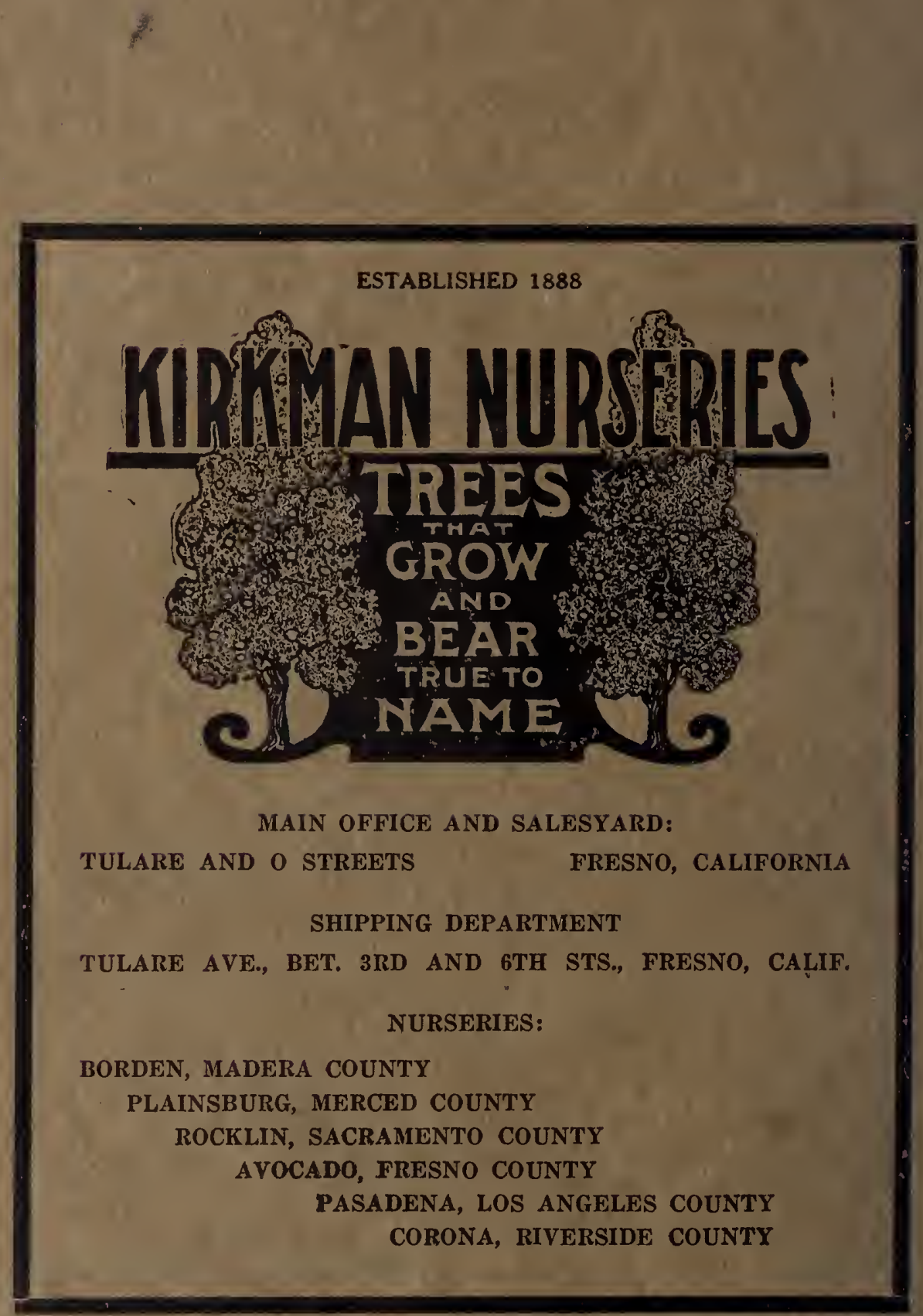

